\title{
Effects of polyvinylpyrrolidone on structural and optical properties of willemite semiconductor nanoparticles by polymer thermal treatment method
}

\author{
Ibrahim Mustapha Alibe ${ }^{1,3}$ (D) Khamirul Amin Matori $^{1,2} \cdot \mathrm{Hj}^{\mathrm{Ab}}$ Aziz Sidek ${ }^{1,2} \cdot$ Yazid Yaakob $^{2} \cdot$ \\ Umer Rashid ${ }^{4}$ (D) - Ali Mustapha Alibe ${ }^{5,6} \cdot$ Mohd Hafiz Mohd Zaid $^{2} \cdot$ Salisu Nasir ${ }^{1} \cdot$ Maharaz Mohammed Nasir $^{2}$
}

Received: 24 March 2018/Accepted: 22 October 2018/Published online: 14 November 2018

(C) The Author(s) 2018

\begin{abstract}
Willemite is an inorganic semiconductor material used for optoelectronic applications. The present study purposes a new polymer thermal treatment method involving calcination temperature to fabricate the willemite nanoparticles. The effects of polyvinylpyrrolidone (PVP) on the structural and optical properties of the material were thoroughly investigated. Thermogravimetric and its derivative confirmed the decomposition behavior of PVP. The minimum calcination temperature to decompose PVP was appraised at $740{ }^{\circ} \mathrm{C}$. The FTIR and the Raman analyses confirmed the presence of organic source before the calcination process and the formation of the crystalline structure of the willemite nanoparticles after the heat treatment. The optimum PVP concentration in this study based on the FTIR results was found to be $40 \mathrm{~g} \mathrm{~L}^{-1}$. This is the minimum concentration at which the willemite nanoparticles remained pure with homogenous distribution. X-ray diffraction analysis of the PVP samples before calcination was confirmed to be amorphous, and upon calcination between 800 and $1000{ }^{\circ} \mathrm{C}$, an $\alpha$-willemite phase was obtained. The morphology and the average particle size were determined with FESEM and HR-TEM analysis. The average particle size is between 23.8 and $36.7 \mathrm{~nm}$. The optical energy band was found to be increasing from 5.24 to $5.32 \mathrm{eV}$ with the corresponding increase in PVP concentration from 20 to $50 \mathrm{~g} \mathrm{~L}^{-1}$. The findings in this study provides a new pathway to understand the effects of PVP concentrations on the structural and optical properties of willemite semiconductor nanoparticles as it may have key potential applications for future optoelectronic devices.
\end{abstract}

\section{Graphical abstract}

The primary task of polyvinylpyrrolidone (PVP) is to serve as a capping agent and to stabilize the metallic salts. The interaction between the PVP and the metallic salts (zinc acetate dihydrate and silicon tetraacetate) is through the strong ionic bonds between the metallic ions and the amide group via oxygen in the PVP chain. The PVP stabilizes the dissolved metallic precursor by amide group steric and electrostatic stabilization. In the drying process at the temperature about $80{ }^{\circ} \mathrm{C}$, the PVP decompose to the shorter polymer chains which they cap the metallic ions. In the step of calcination at the range of $900{ }^{\circ} \mathrm{C}$ for $1-4 \mathrm{~h}$, the polymer content and unwanted anions are entirely removed and the nucleation of willemite nanoparticles achieved.

Ibrahim Mustapha Alibe

babaiya1@gmail.com

$\triangle$ Khamirul Amin Matori

khamirul@upm.edu.my

Extended author information available on the last page of the article 


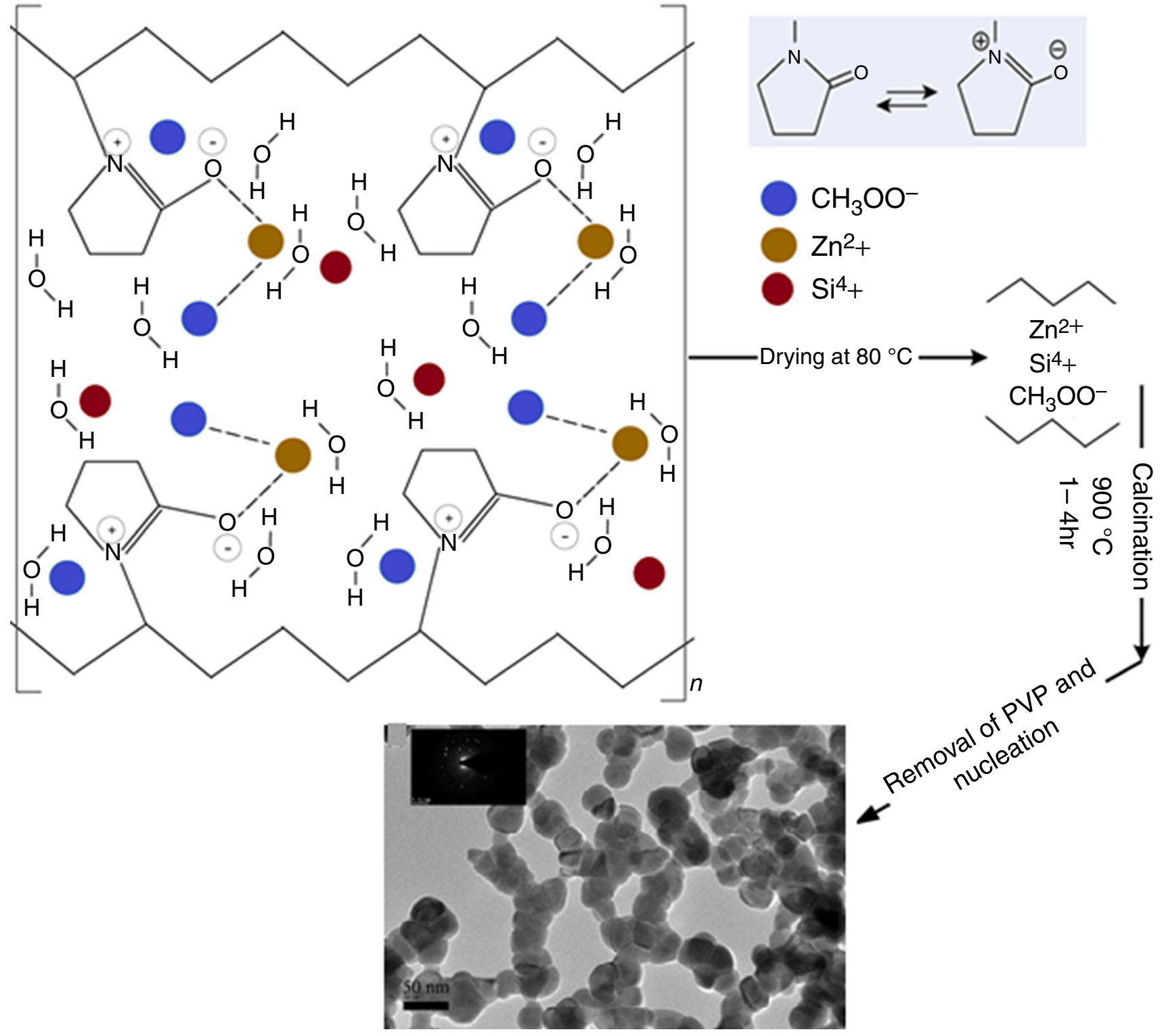

A proposed mechanism of interaction for metal ions and PVP in the of formation willemite NPs.

Keywords Polyvinylpyrrolidone $\cdot$ Band gap $\cdot$ Semiconductors $\cdot$ Willemite $\cdot$ Nanoparticles $\cdot$ Calcination

\section{Introduction}

Polymers are currently attracting considerable research attention because of their broad industrial applications. Basic polymer features such as easy production, low initial cost, durability and exceptional processability necessitate its use in several scientific applications [1,2]. Besides, some other characteristics of polymers such as hydrophobic/hydrophilic balance, bio-compatibility, optoelectronic behavior, chemical stability and functionalities (i.e., solvation, wettability, templating effect) should be considered in the selection of the polymers for a particular kind of application. The greatest challenges in the field of polymer science are to develop the application means of such materials while maintaining the aforementioned properties and improving certain features like strength, modulus, fire performance and heat resistance [3]. Polymers in many instances can also tolerate easier shaping and better 
processing of the composite materials. It has been reported that a polymer matrix can be used in the formation of nanoparticle (NPs) owing to the fact that it carries the features of the host polymer matrix and the guest nanoparticles [4-8].

Inorganic metal oxide semiconductor NPs formed in the polymer matrices had attracted significant attention, due to the outstanding characteristics of the materials [9-12].The NPs fabricated in such manner exhibited interesting properties such as optical, electrical, magnetic, catalytic, and mechanical features that were distinct from those observed in their molecular and bulk materials counterparts [13-15]. Willemite or zinc silicate $\left(\mathrm{Zn}_{2} \mathrm{SiO}_{4}\right)$ belongs to the families of functional inorganic semiconductor materials, and it has been reported to have potentials for phosphors applications [16-18]. For example, in photonic devices [19, 20], laser crystals [21, 22], optoelectronics [23, 24], as well as adsorbents [25, 26]. Several investigations regarding the synthesis techniques of willemite have been reported by numerous researchers, including the sol-gel technique [27, 28], solid-state route [18, 29-31], co-precipitation method [32], spray pyrolysis method [33] spray drying method [34], hydrothermal method [35, 36], supercritical methods [37, 38], solvothermal method [39] and sonochemical method [40]. Conventional sol-gel and solid-state technique are often used methods for producing willemite NPs for phosphor application. In this context, Rasdi et al. [41] used the sol-gel technique to synthesize willemite nanophosphors at the calcination temperature of $1000{ }^{\circ} \mathrm{C} /$ $2 \mathrm{~h}$ and obtained an average particle size of $181 \mathrm{~nm}$. Similarly, Babu and Buddhudu [42] produced willemite NPs with a mean particle size of $100 \mathrm{~nm}$. However, this involves a very long reaction period by allowing the precursor to be evaporated naturally in the air for 2 or 3 months and later calcined at $950{ }^{\circ} \mathrm{C}$ for $2 \mathrm{~h}$. On the other hand, solid-state technique often involves higher calcination temperature as compared to sol-gel, usually ranging between 1000 and $1500{ }^{\circ} \mathrm{C}[18,30,31]$. For instance, Diao et al. [43] fabricated willemite NPs with average size larger than $200 \mathrm{~nm}$ using solid-state technique at a temperature between 900 and $1300{ }^{\circ} \mathrm{C}$. It was inferred that willemite NPs synthesized by hydrothermal routes mostly involves low calcination temperature ranging between 200 and $280{ }^{\circ} \mathrm{C}$ but lengthy heating period [44, 45]. In this light, $\mathrm{Xu}$ et al. [46] fabricated willemite nanorods with a width and length of about $0.25 \times 1 \mu^{2}$ by mixing the solvent of ethylene diamine and water at $200{ }^{\circ} \mathrm{C}$ for 6 days. However, most of the techniques mentioned involved high pressure or heat treatment for several hours and in some cases, toxic chemicals or the reagents that are detrimental to the environment as well. Such problems can be curtailed by using a polymer thermal treatment method. In this context, the present study investigated the effects of the concentration of PVP that induced the formation of willemite NPs with distinct morphology. The structural and optical behaviors of the material obtained by varying the PVP concentrations were particularly emphasized.

\section{Experimental}

\section{Materials preparation}

Zinc acetate dihydrate $\left[\mathrm{Zn}\left(\mathrm{CH}_{3} \mathrm{COO}\right)_{2} \cdot 2 \mathrm{H}_{2} \mathrm{O}\right] \quad\left(\mathrm{M}_{\mathrm{w}}=\right.$ $\left.219.49 \mathrm{~g} \mathrm{~mol}^{-1}\right)$ and silicon tetraacetate reagent " $\left[\mathrm{Si}\left(\mathrm{CH}_{3} \mathrm{COO}\right)_{4}\right]\left(\mathrm{M}_{\mathrm{w}}=264.26 \mathrm{~g} \mathrm{~mol}^{-1}\right)$ metallic precursors were purchased from Sigma-Aldrich. Polyvinylpyrrolidone (PVP $\mathrm{M}_{\mathrm{w}}=29,000 \mathrm{~g} \mathrm{~mol}^{-1}$ ) was also purchased from Sigma-Aldrich and used as a source of polymer to act as a capping agent in order to reduce agglomeration and stabilize the NPs. Deionized water having a resistivity of $18.2 \mathrm{M} \Omega \mathrm{cm}^{-1}$ and conductivity of $0.055 \mu \mathrm{S} \mathrm{cm}^{-1}$ was used as a solvent. The purity of all the chemicals used was more than 99\%; therefore, no further purification was carried out.

Aqueous solutions of various PVP concentrations (0, 20, 30,40 and $50 \mathrm{~g} \mathrm{~L}^{-1}$ ) were prepared in a liter of deionized water. The solutions were steadily stirred at $70{ }^{\circ} \mathrm{C}$ for $2 \mathrm{~h}$ using a magnetic stirrer, and a clear homogeneous solution was obtained. The metallic precursors with $0.1 \mathrm{mmol}$ of zinc acetate dihydrate and $0.1 \mathrm{mmol}$ of silicon tetraacetate were incorporated into the solution and further stirred for $2 \mathrm{~h}$. The solution was then transferred to a clean glass Petri dish, and the water was allowed to evaporate at $80{ }^{\circ} \mathrm{C}$ in an electric oven overnight. The resulting dried solid obtained was crushed into powder using mortar and pestle. The powdered sample was then transferred to crucible boats and placed in an electric furnace for calcination at the temperatures ranging between 800 and $1000{ }^{\circ} \mathrm{C}$ for $3 \mathrm{~h}$, respectively. A constant heating rate of $5{ }^{\circ} \mathrm{C} \min ^{-1}$ was used throughout the process for the decomposition of the organic components and crystallization of the material. In this instance, the polymer (PVP) played the role of a capping agent that contributed a vital part to the formation of the willemite nanoparticle. The metallic ions were entrapped by the ionic-dipole interaction with an amine group in the polymeric chains. The system was followed by a mobility congealment of the metallic cations in the polymer cavity due to the elimination of water by simply drying the mixture [47, 48].

\section{Characterization}

In this study, a range of techniques were employed to examine the influence of PVP concentration on the properties of the as-prepared willemite NPs. Thermogravimetric 
analysis (TGA) and its derivative (DTG) were conducted using a TGA/DSC 1HT model (METTLER TOLEDO, Shah Alam, Selangor, Malaysia). The decomposition properties of the PVP were measured under natural conditions (in air atmosphere) within a temperature range between 30 and $1200{ }^{\circ} \mathrm{C}$ at $10{ }^{\circ} \mathrm{C} \mathrm{min}{ }^{-1}$. The structural behavior of the crystalline sample was analyzed using X-ray diffraction spectrometer (XRD Shimadzu model 6000 Lelyweg1, Almelo, Netherlands) using $\mathrm{Cu} \mathrm{K \alpha}$ $(0.154 \mathrm{~nm})$ as a radiation source to generate diffraction peaks from the sample within a $2 \theta$ angle range of $10^{\circ}-80^{\circ}$. The bond formation of the samples before and after calcination was studied using infrared spectroscopy (FTIR, Perkin Elmer model 1650, Labexchange, Swabian Burladingen, Germany). The Raman spectroscopic analysis of the samples before and after calcination process was conducted using a 'Wissenschaftliche Instrumente und Technologie' (WITec) Raman spectrometer, Alpha 300R (WITec GmbH, Ulm, Germany). The Raman frequency was acquired with a laser excitation wavelength of $532 \mathrm{~nm}$ and an integration time of 5.03645 "s". The morphology and consistency of NPs were examined using a field emission scanning electron microscope FESEM with an accelerating voltage of $5 \mathrm{kV}$ equipped with EDX using an FEI Nova NanoSEM 230 (FEI, Hillsboro, OR, USA).The particle size distribution was observed by high-resolution transmission electron microscopy (JEOL HR-TEM model 3010 , USA) with an accelerating voltage of $200 \mathrm{kV}$. The absorption properties were probed using the UV-vis spectrometer (Shimadzu model UV-3600, Kyoto, Japan) and photoluminescence (PL) (Perkin Elmer LS 55, Waltham, MA, USA) was used to analyze the optical properties of the materials at room temperatures, within the wavelength of $200-800 \mathrm{~nm}$.

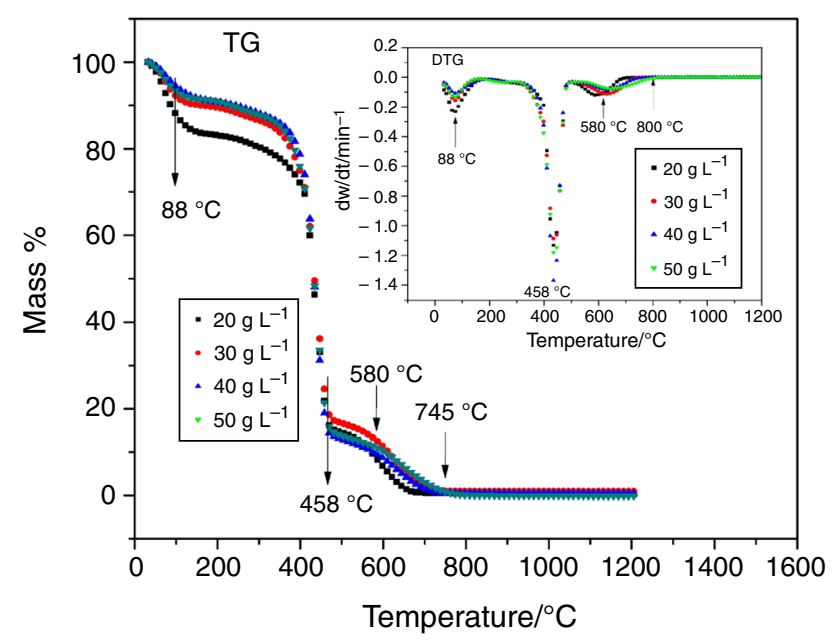

Fig. 1 Thermogravimetric (TG) and thermogravimetric derivative (DTG) curves for PVP at a heating rate of $10^{\circ} \mathrm{C} \mathrm{min}^{-1}$
Fig. 2 FT-IR spectra of willemite NPs over a range of PVP amounts: a different amounts of PVP at $30^{\circ} \mathrm{C}$, b $20 \mathrm{~g} \mathrm{~L}^{-1}$, c $30 \mathrm{~g} \mathrm{~L}^{-1}$, d $40 \mathrm{~g} \mathrm{~L}^{-1}$, e $50 \mathrm{~g} \mathrm{~L}^{-1}$

\section{Results and discussion}

\section{TGA-DTG measurements}

Thermal analysis and the pyrogenation behavior of metallic salt in combination with PVP at different concentrations (20-50 $\mathrm{g} \mathrm{L}^{-1}$ ) offers essential information regarding the optimal temperature to commence the calcination process as well as the decomposition behavior of PVP. This is generally determined by the TGA-DTG analysis. The mass loss percentage as a function of the temperature of all the PVP amounts before the calcination process is presented in Fig. 1. The spectra exhibit three distinct decomposition stages. The initial decomposition observed at $88^{\circ} \mathrm{C}$ (which corresponds to about $12 \%$ mass loss) could be attributed to moisture content in the sample [47]. The second stage of decomposition occurred at $458{ }^{\circ} \mathrm{C}$ which is equivalent to $78 \%$ mass loss indicated that most of the organic materials (PVP) have been disintegrated [48]. No significant mass loss was recorded as the temperature reaches $580{ }^{\circ} \mathrm{C}$, which may be due to the complete decomposition of the PVP, thereby turning it into a carbonaceous product, hence, only the metal oxide remains as a final residue [48]. Thus, the analysis reveals that for the fabrication of willemite NPs, the optimum calcination temperature must be maintained beyond $745{ }^{\circ} \mathrm{C}$. This is in agreement with the relevant studies which also claim that the formation temperature of willemite phase is between 700 and $800{ }^{\circ} \mathrm{C}$ $[27,40]$.

\section{FTIR analysis}

FTIR spectroscopy aids in analyzing multi-component functional groups and gives relevant information regarding the material phase composition and the nature of interaction existing in various kinds of bond in the samples at all concentration of PVP before and after calcination. In this work, FTIR technique was employed to investigate the ideal PVP concentration at which willemite NPs can be formed without the presence of an organic source. The spectra are shown in Fig. $2 \mathrm{a}$ and measured at $30{ }^{\circ} \mathrm{C}$ reveal the existence of several organic sources related to PVP. Table 1 reveals the various FTIR vibrational bands and their assignment related to PVP and those of willemite NPs. The vibrational bands of $\mathrm{C}=\mathrm{O}$ stretching vibration, $\mathrm{C}-$ $\mathrm{H}$ and $\mathrm{N}-\mathrm{H}$ are detected at the wavenumber of 1648,2945 , and $3414 \mathrm{~cm}^{-1}$, respectively [47]. The peak shown at $1428 \mathrm{~cm}^{-1}$ is ascribed to $\mathrm{C}-\mathrm{H}$ bending vibrations that have 

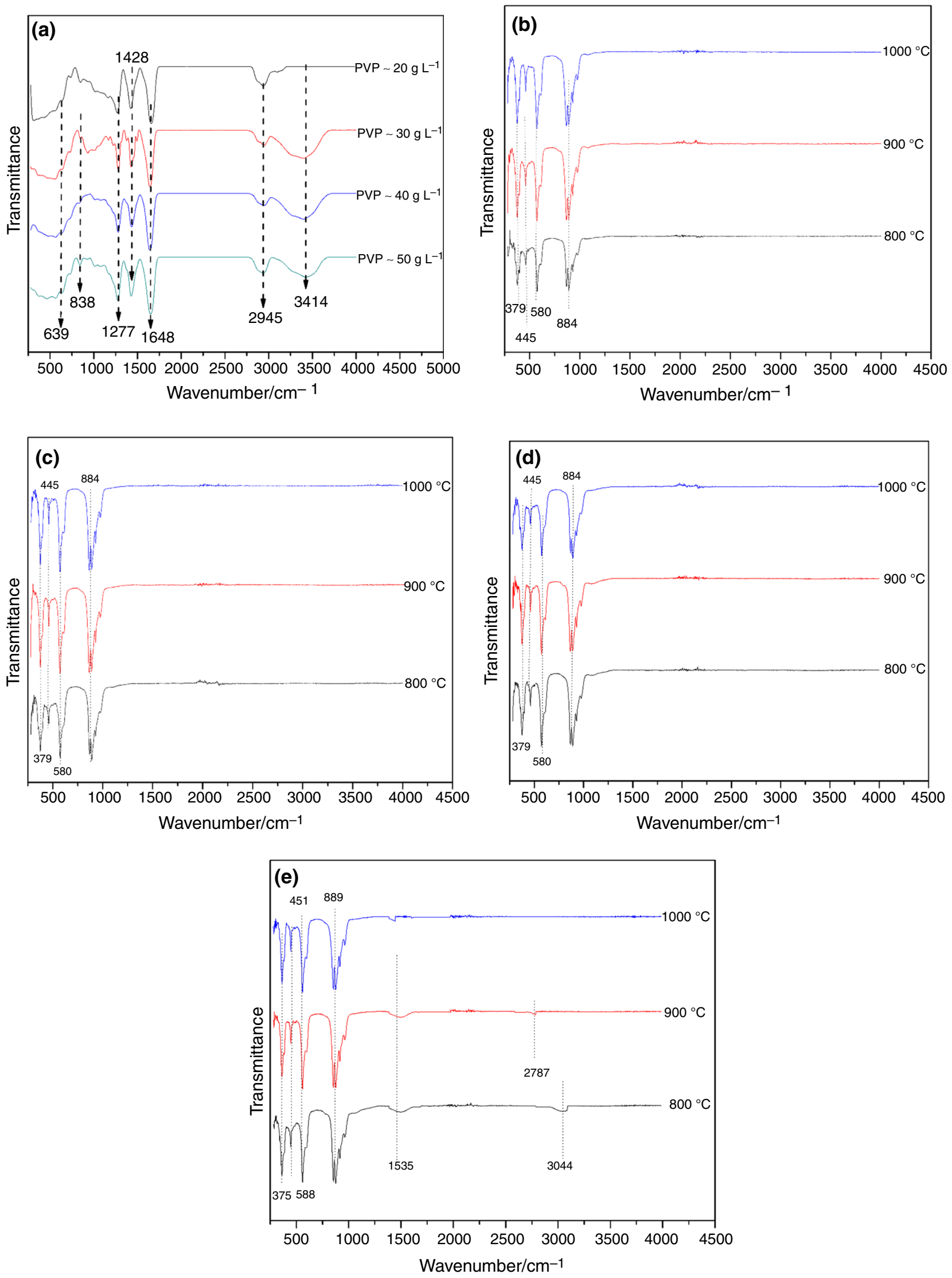
Table 1 Summary of the FTIR absorption features and their assignments

\begin{tabular}{lll}
\hline Wave number $/ \mathrm{cm}^{-1}$ & Assignment of vibration mode & References \\
\hline $379-441$ & Zn-O symmetric stretching vibration & {$[40,50]$} \\
$580-588$ & Zn-O asymmetric stretching vibration & {$[40,50]$} \\
$885-889$ & Si-O stretching vibration & {$[40,49,50]$} \\
$639-641$ & C-N=O bending vibration & {$[49]$} \\
837 & C-C ring vibration & {$[49]$} \\
1277 & C-N stretching vibration & {$[49]$} \\
$1402-1460$ & C-H- bending vibration of methylene group & {$[9,48]$} \\
1648 & C=O stretching vibration & {$[47]$} \\
2945 & C-H vibration & {$[47]$} \\
3414 & N-H bending vibration & {$[47]$} \\
\hline
\end{tabular}

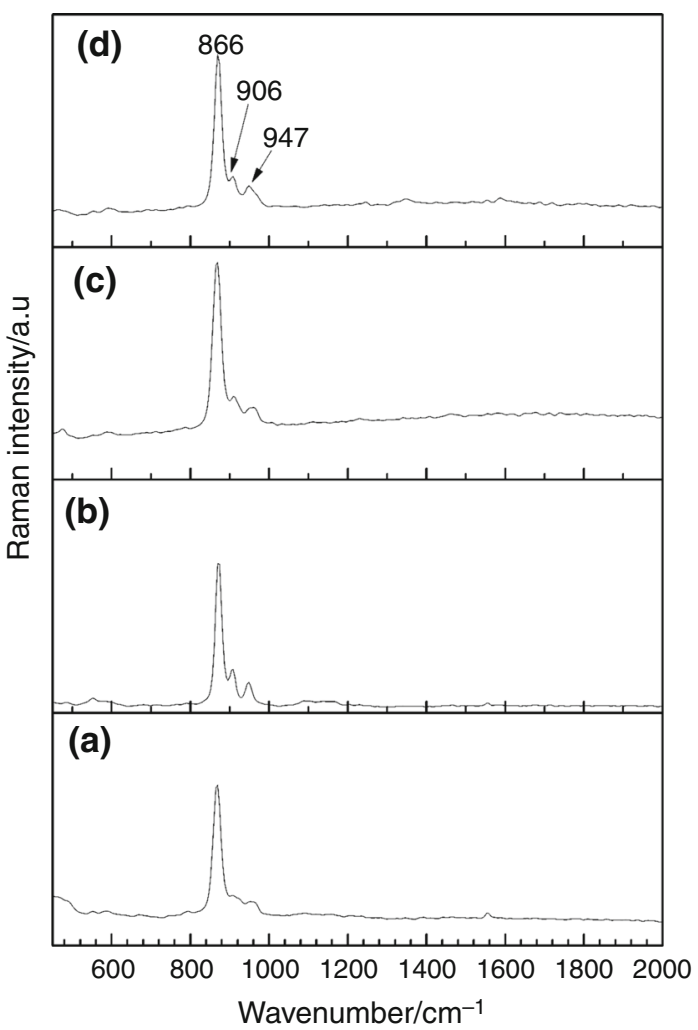

Fig. 4 Raman spectra of willemite NPs calcined at $900{ }^{\circ} \mathrm{C}$ over a range of PVP amounts a $20 \mathrm{~g} \mathrm{~L}^{-1}$, b $30 \mathrm{~g} \mathrm{~L}^{-1}$, c $40 \mathrm{~g} \mathrm{~mL}^{-1}$, d $50 \mathrm{~g} \mathrm{~L}^{-1}$

at 884 , and $889 \mathrm{~cm}^{-1}$, are associated with $\mathrm{Si}-\mathrm{O}$ stretching vibration $[40,49,50]$. The slight shift in the wave number observed is due to an increase in the calcination temperature as it affects the particle size of the material [50]. The findings in this work obtained from the FT-IR results revealed that pure and smaller willemite NPs have been achieved at a calcination temperature of $900{ }^{\circ} \mathrm{C}$ with $40 \mathrm{~g} \mathrm{~L}^{-1}$ concentration of PVP. Therefore, the calcination temperature of $900{ }^{\circ} \mathrm{C}$ is adopted as the optimum condition 
Table 2 Summary of the Raman absorption features and their assignments

\begin{tabular}{lll}
\hline Wave number $/ \mathrm{cm}^{-1}$ & Assignment of vibration mode & References \\
\hline $300-700$ & Bending vibration of $\mathrm{SiO}_{4}$ group & {$[53,54]$} \\
$800-1100$ & Stretching vibration of $\mathrm{SiO}_{4}$ group & {$[53,54]$} \\
868 & Crystalline $\mathrm{Zn}_{2} \mathrm{SiO}_{4}$ vibration peak & {$[54]$} \\
758 & Ring C-C vibration & {$[51]$} \\
855 & $\mathrm{C}-\mathrm{C}$ stretching vibration & {$[51]$} \\
934 & $\mathrm{C}-\mathrm{C}$ ring breathing & {$[51,52]$} \\
1023 & $\mathrm{C}-\mathrm{C}$ back bone & {$[51,52]$} \\
1370 & $\mathrm{C}-\mathrm{H}$ deformation & {$[51,52]$} \\
1494 & $\mathrm{CH}$ scissors & {$[51]$} \\
1665 & $\mathrm{C}=\mathrm{O}$ & {$[51]$}
\end{tabular}

for producing willemite NPs with minimum energy consumption.

\section{Raman spectroscopy analysis}

The Raman spectroscopy analysis was used to determine the organic and the inorganic behavior of the samples before and after calcination as shown in Figs. 3 and 4, respectively. It could be noted that only samples calcined at $900{ }^{\circ} \mathrm{C}$ and prepared with the PVP amounts between 20 and $50 \mathrm{~g} \mathrm{~L}^{-1}$ were analyzed using this technique. From the spectrum in Fig. 3, the sample analyzed at room temperature (before calcination) exhibits a vibrational band due to several organic sources related to the polymer (PVP). Table 2 presents the Raman vibrational bands and their assignments. The peak at $758 \mathrm{~cm}^{-1}$ is assigned to the $\mathrm{C}-\mathrm{C}$ ring vibration, while the peak at 934 is due to $\mathrm{C}-\mathrm{C}$ ring breathing [51]. The $\mathrm{C}-\mathrm{C}$ backbone is observed at $1023 \mathrm{~cm}^{-1}$, and the peak at $1370 \mathrm{~cm}^{-1}$ is due to the $\mathrm{CH}$ deformation [51, 52]. The band at $1665 \mathrm{~cm}^{-1}$ is for $\mathrm{C}=\mathrm{O}$, while the peak at $1494 \mathrm{~cm}^{-1}$ is ascribed to $\mathrm{CH}_{2}$ scissors vibration [51]. Upon the calcination at $900{ }^{\circ} \mathrm{C}$, the samples with various PVP amounts $\left(20-50 \mathrm{~g} \mathrm{~L}^{-1}\right)$ as illustrated in Fig. 4 demonstrate an inorganic behavior of the willemite NPs. The bending vibration of the $\mathrm{SiO}_{4}$ group is observed between 300 and $700 \mathrm{~cm}^{-1}$, while the stretching vibration for $\mathrm{SiO}_{4}$ is found between 800 and $1100 \mathrm{~cm}^{-1}$ [53, 54]. The most intense peak at $866 \mathrm{~cm}^{-1}$ is attributed to the willemite NPs crystalline vibrational band [55]. However, the intensity of the Raman peak was reduced with the corresponding increase in the PVP concentration (Fig. 4) and this may be owed to the reduction of the particle size of the willemite NPs at higher PVP concentrations.

\section{X-ray diffraction analysis}

The effect of the PVP concentration on the formation and crystalline behavior of the willemite NPs, the samples were studied without PVP $\left(0.00 \mathrm{~g} \mathrm{~L}^{-1}\right)$ and with different PVP concentrations (20-50 $\left.\mathrm{g} \mathrm{L}^{-1}\right)$. The samples prepared in the absence of PVP are shown in Fig. 5a. These materials were calcined within the temperature range of $800-1000{ }^{\circ} \mathrm{C}$, and interestingly, the polycrystalline phase of $\alpha$-willemite is formed at all the calcination temperatures, except for a trace of unreacted $\mathrm{ZnO}$, which is observed at $2 \theta=34.48$ and $68.03^{\circ}$. However, the sample prepared in the presence of PVP ( $\left.40 \mathrm{~g} \mathrm{~L}^{-1}\right)$ before calcination (at room temperature) presented in Fig. 5b indicates an amorphous phase due to the broad hump observed in the spectra. Moreover, a clear peak which is generally associated with the crystallinity of the material was also not formed in the sample [47-49]. Furthermore, Fig. 5c-f presents the samples prepared with PVP concentration of (20-50 $\left.\mathrm{g} \mathrm{L}^{-1}\right)$ and calcined between 800 and $1000{ }^{\circ} \mathrm{C}$. Samples calcined at $800{ }^{\circ} \mathrm{C}$ for all the PVP amount exhibit $\alpha$-willemite and also an unreacted $\mathrm{ZnO}$ phase at the peak position of $2 \theta=36.40^{\circ}$ which corresponds to the 011 plane of the latter. As the calcination temperature is elevated to 900 and $1000{ }^{\circ} \mathrm{C}$, respectively, for all the PVP amounts, it resulted in the proper formation of $\alpha$-willemite phase with all the diffraction peaks indexed to the standard pattern of $\alpha$ willemite (JCPDS No 37-1485), with the space group of $\mathrm{R}-3$, and cell constants $a=b=13.947 \AA, c=9.3124 \AA$. No obvious impurities phase was detected. In addition, in Fig. 6, the XRD standard reference pattern and the peak list of the samples prepared in the absence of PVP and with $40 \mathrm{~g} \mathrm{~L}^{-1}$ calcined at $900{ }^{\circ} \mathrm{C}$ were presented. The formation temperature of the willemite phase was reported to be between 700 and $800{ }^{\circ} \mathrm{C}$, and this is condition under which the $\mathrm{ZnO}$ crystal's quality will collapse [40, 50]. Hence, $\mathrm{ZnO}$ atom, being at the surface, will dominantly diffuse the silica matrix thus inducing the formation of willemite $[40,50]$. However, further calcination at a higher temperature will also make the process of diffusion to accelerate rapidly. Therefore, the crystallinity of the willemite NPs will, in turn, advance with the increase in the calcination temperature. Furthermore, it is fascinating to note that the temperature at which the willemite phase was formed in 

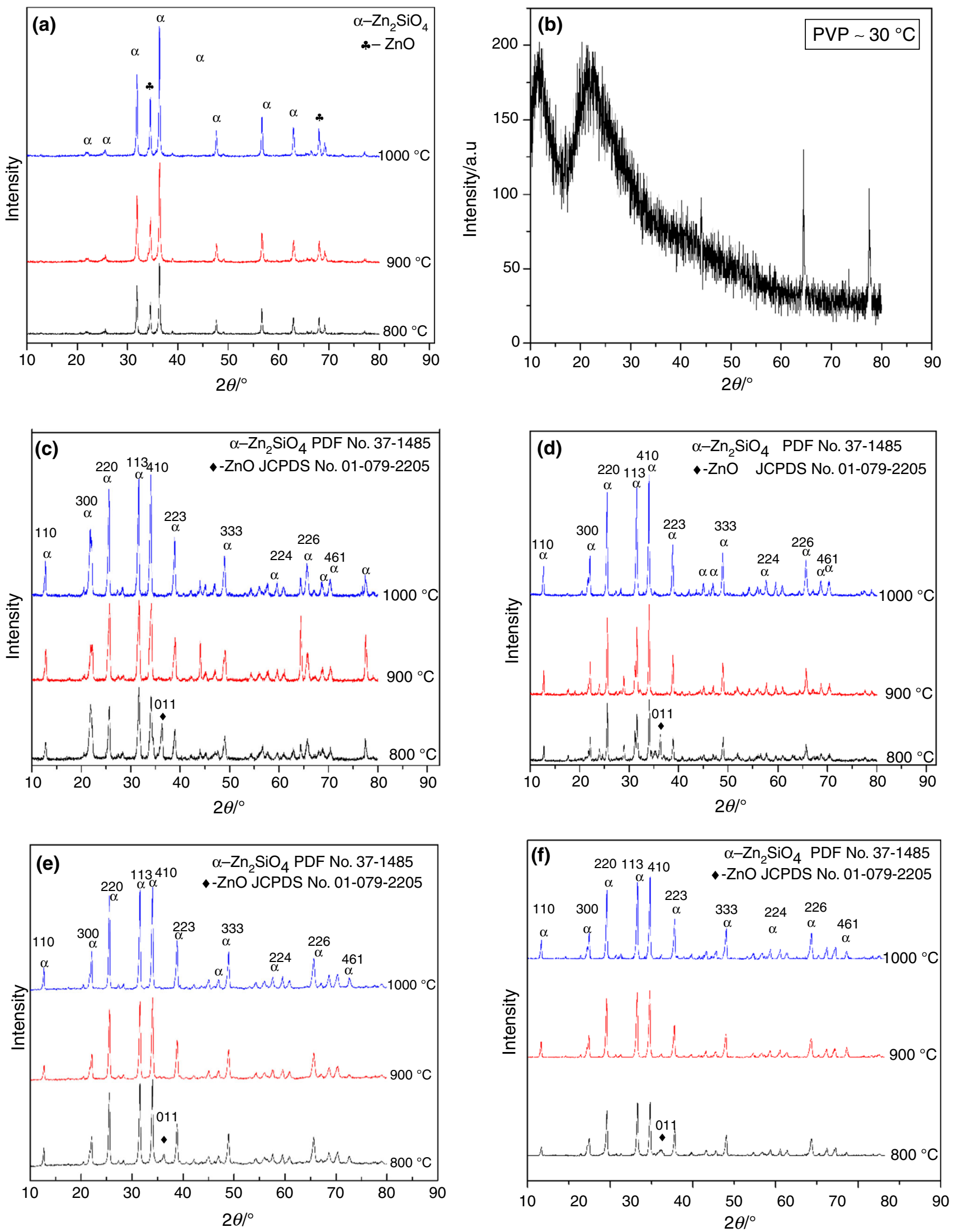
4Fig. 5 XRD patterns of willemite NPs obtained following calcination involving range of PVP concentration. a $0.00 \mathrm{~g} \mathrm{~L}^{-1}$, b PVP at $30{ }^{\circ} \mathrm{C}$ c $20 \mathrm{~g} \mathrm{~L}^{-1}$, d $30 \mathrm{~g} \mathrm{~L}^{-1}$, e $40 \mathrm{~g} \mathrm{~L}^{-1}$, f $50 \mathrm{~g} \mathrm{~L}^{-1}$
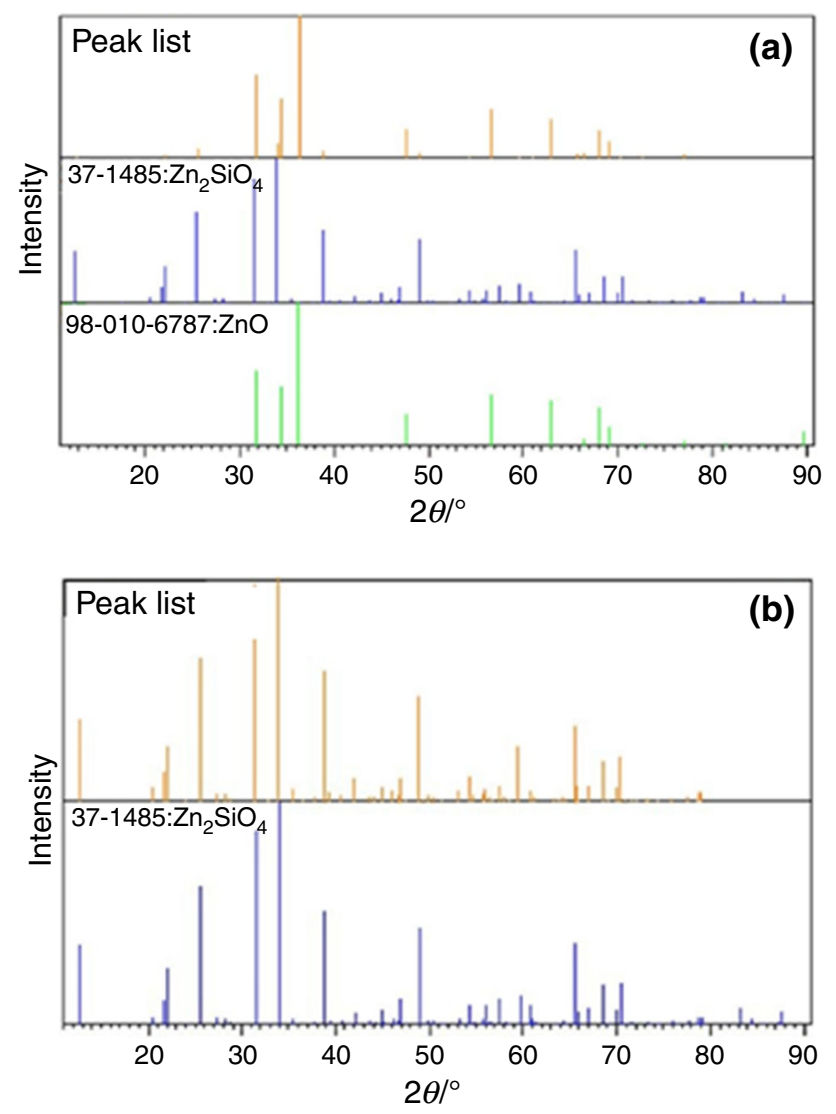

Fig. 6 XRD reference patterns of willemite NPs produced at $900{ }^{\circ} \mathrm{C}$ : a $0.0 \mathrm{~g} \mathrm{~L}^{-1}$ in the absence of PVP, b $40 \mathrm{~g} \mathrm{~L}^{-1}$ PVP concentration

this work $\left(900^{\circ} \mathrm{C}\right)$ was considerably lower than the annealing temperature $\left(1400{ }^{\circ} \mathrm{C}\right)$ of the conventional solidstate method as reported by Al-Nidawi et al. [56] and Mohamed et al. [57]. Furthermore, it is also a $300{ }^{\circ} \mathrm{C}$ lower than the temperature $\left(1200{ }^{\circ} \mathrm{C}\right)$ reported by $\mathrm{El}$ Ghoul et al. [58] using in the sol-gel method.

The famous Scherer's formula was used to calculate the mean crystalline diameter of the willemite NPs for the most intense peak as shown in the equation below.

$D=0.94 \lambda / \beta \cos \theta$ where $D$ is the crystalline size measured in $(\mathrm{nm}), \beta$ is the full width of the observed diffraction at half of the maximum intensity measured in radians, $\theta$ is the Bragg's angle and $\lambda$ is $\mathrm{X}$-ray wavelength of $\mathrm{CuK} \alpha(0.154 \mathrm{~nm})$ [40]. It can be deduced that the crystalline size was found to be reducing from 36.7 to $23.8 \mathrm{~nm}$ with the increase in the PVP concentration (20-50 $\mathrm{g} \mathrm{L}^{-1}$ ) for the willemite NPs produced at $900{ }^{\circ} \mathrm{C}$ as shown in Table 3 .

\section{Morphological analysis}

The particle distribution and surface morphology behavior of the prepared willemite NPs were assessed using the FESEM. The images were captured at $5 \mathrm{kV}$ operating voltage. In this study, only the FESEM images of those samples calcined at $900{ }^{\circ} \mathrm{C}$ within the PVP amounts of 20-50 $\mathrm{g} \mathrm{L}^{-1}$ were reported as shown in Fig. 7. The willemite NPs produced without PVP shown in Fig. 7a exhibits an irregular shape and morphology. This is due to the elevation in the surface energy of the material where the tiny NPs gather together and fuse into one another, thus forming larger particles [59]. The willemite NPs formed with lower PVP concentration of 20 and $30 \mathrm{~g} \mathrm{~L}^{-1}$ seem to possess higher sign of agglomeration that exhibits nonhomogeneity in the particles distribution. However, the willemite NPs synthesized with higher PVP concentration (40 and $50 \mathrm{~g} \mathrm{~L}^{-1}$ ) exhibited a uniform morphology and nearly hexagonal shape particle distribution. In comparison with other related works reported previously, shown in Table 4, willemite NPs produced via polymer thermal treatment method is more promising in terms of low production cost, better distribution of particle size, shorter reaction period, low calcination temperature, and lack of harmful chemicals released to the environment. The elemental composition of the samples calcined at $900{ }^{\circ} \mathrm{C}$ for all the PVP concentrations was examined using the EDX analysis as depicted in Fig. 8. The presence of Zinc, Silicon, and Oxygen in the entire samples marked by their respective peaks was confirmed by the EDX machine. There were no impurities or loss of the element been observed during the calcination process. This corroborates with the findings reported by other researchers [40].
Table 3 Summary of the structural and optical features of the synthesized willemite NPs calcined at $900{ }^{\circ} \mathrm{C}$ with different PVP amounts

\begin{tabular}{llllll}
\hline PVP concentration $/ \mathrm{g} \mathrm{L}^{-1}$ & Peak position/20 & FWHM & $D_{\mathrm{XRD}} / \mathrm{nm}$ & $D_{\mathrm{TEM}} / \mathrm{nm}$ & $E_{\mathrm{g}} / \mathrm{eV}$ \\
\hline 20.0 & 34.08 & 0.266 & 32.64 & 36.70 & $5.24 \pm 0.04$ \\
30.0 & 33.98 & 0.301 & 28.36 & 31.60 & $5.26 \pm 0.04$ \\
40.0 & 33.96 & 0.351 & 24.20 & 26.20 & $5.28 \pm 0.04$ \\
50.0 & 33.95 & 0.389 & 22.29 & 23.80 & $5.32 \pm 0.04$ \\
\hline
\end{tabular}



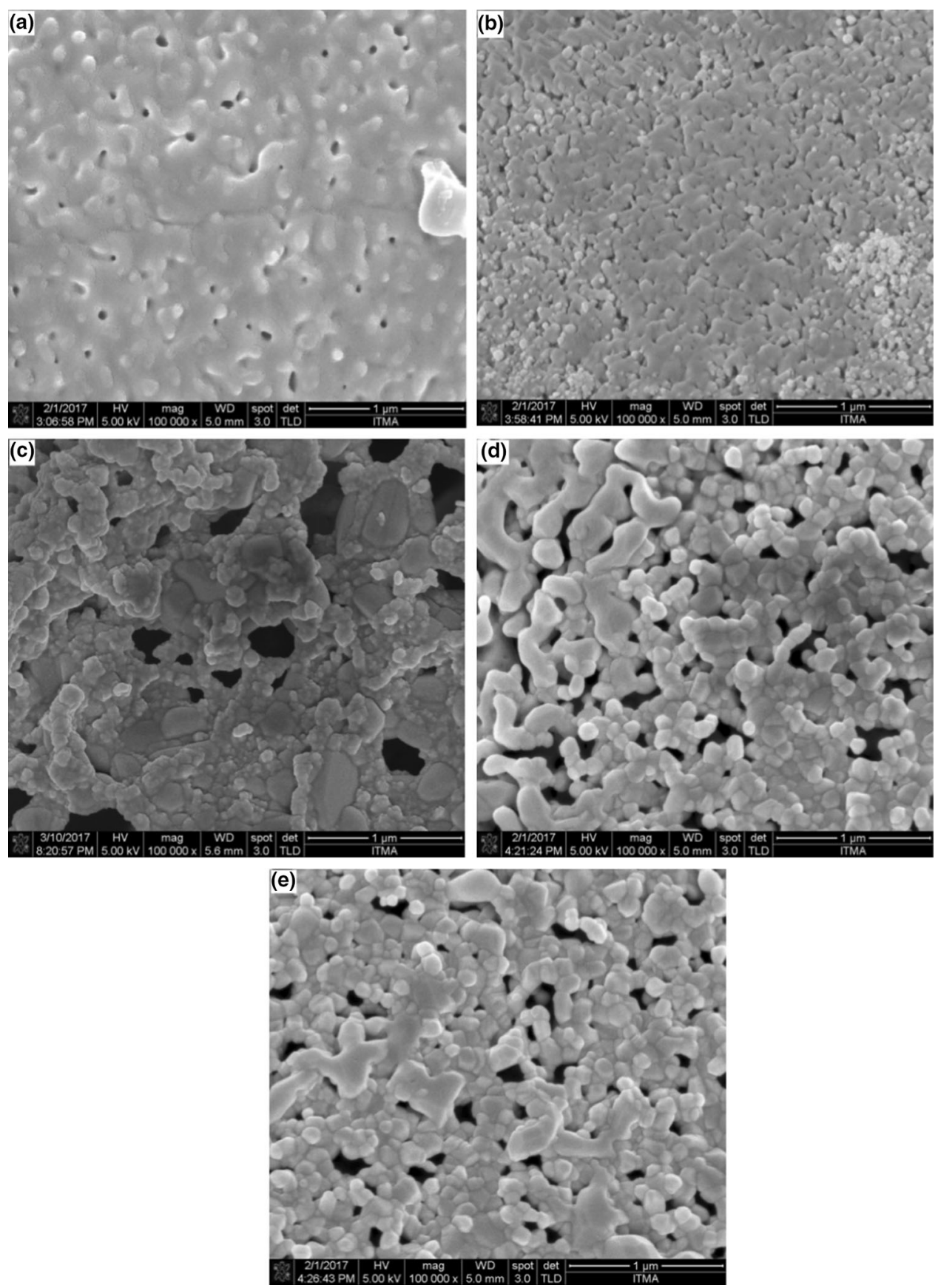

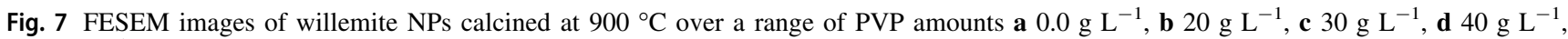
e $50 \mathrm{~g} \mathrm{~L}^{-1}$

\section{HR-TEM analysis}

The HR-TEM images in Fig. 9a-o show the particle size distribution, lattice distance, and selective area electron diffraction (SAED) for the willemite NPs synthesized at $900{ }^{\circ} \mathrm{C}$ at various PVP concentrations. The sample produced without PVP presented in Fig. 9a-c shows a higher sign of particle agglomeration and non-homogeneity in the material. This is attributed to the lack of PVP in the sample which results in Ostwald ripening growth mechanism, where small crystals or particles are fused and redeposited onto larger crystals or particles [40,60]. In the same context, Fig. 9d-o exhibits the HR-TEM images for the willemite NPs prepared in the presence of PVP $\left(20-50 \mathrm{~g} \mathrm{~L}^{-1}\right)$ calcined at $900{ }^{\circ} \mathrm{C}$. The results indicate more homogeneous spread and even nanoparticle size dispersal with higher 
Table 4 Characterization comparison of the produced willemite NPs obtained with other similar work

\begin{tabular}{|c|c|c|c|c|c|}
\hline Method & Precursors & $\begin{array}{l}\text { Synthesis } \\
\text { conditions }\end{array}$ & $\begin{array}{l}\text { Particle } \\
\text { size/nm }\end{array}$ & Morphology & References \\
\hline Solid state & $\mathrm{ZnO}$, white rice husk ash & $1400^{\circ} \mathrm{C}, 2 \mathrm{~h}$ & $500-1000$ & Non-uniform particles distribution & {$[57]$} \\
\hline Hydrothermal & Zinc nitrate, sodium silicate & $700^{\circ} \mathrm{C}, 10 \mathrm{~h}$ & $300-1000$ & Non-uniform particle distribution & [35] \\
\hline $\begin{array}{l}\text { Super critical } \\
\text { water }\end{array}$ & Zinc acetate dihydrate & $\begin{array}{l}400{ }^{\circ} \mathrm{C} \\
29 \mathrm{MPa}, 24 \mathrm{~h}\end{array}$ & $500-1000$ & Non-uniform nanorods, distribution & {$[37]$} \\
\hline Sol-gel method & $\begin{array}{l}\text { Tetraethylorthosilicate, and zinc } \\
\text { acetate dihydrate }\end{array}$ & $1500{ }^{\circ} \mathrm{C}, 2 \mathrm{~h}$, & $60-98$ & Non-uniform particles distribution & {$[27]$} \\
\hline Spray pyrolysis & $\begin{array}{l}\text { Zinc nitrate, tetraethyl orthosilicate, } \\
\text { Nitric acid }\end{array}$ & $1200{ }^{\circ} \mathrm{C}, 5 \mathrm{~h}$ & $650-1250$ & $\begin{array}{l}\text { Non-uniform particles distribution } \\
\text { agglomerated }\end{array}$ & {$[33]$} \\
\hline Sonochemical & $\begin{array}{l}\text { Tetraethylorthosilicate, and zinc } \\
\text { acetate dihydrate }\end{array}$ & $950{ }^{\circ} \mathrm{C}, 2 \mathrm{~h}$ & 50 & Uniform distribution & {$[40]$} \\
\hline $\begin{array}{l}\text { Simple polymer } \\
\text { synthesis }\end{array}$ & $\begin{array}{l}\text { Zinc acetate dihydrate Silicon } \\
\text { tetraacetate }\end{array}$ & $900{ }^{\circ} \mathrm{C}, 3 \mathrm{~h}$ & 26 & Uniform nanoparticle & This paper \\
\hline
\end{tabular}
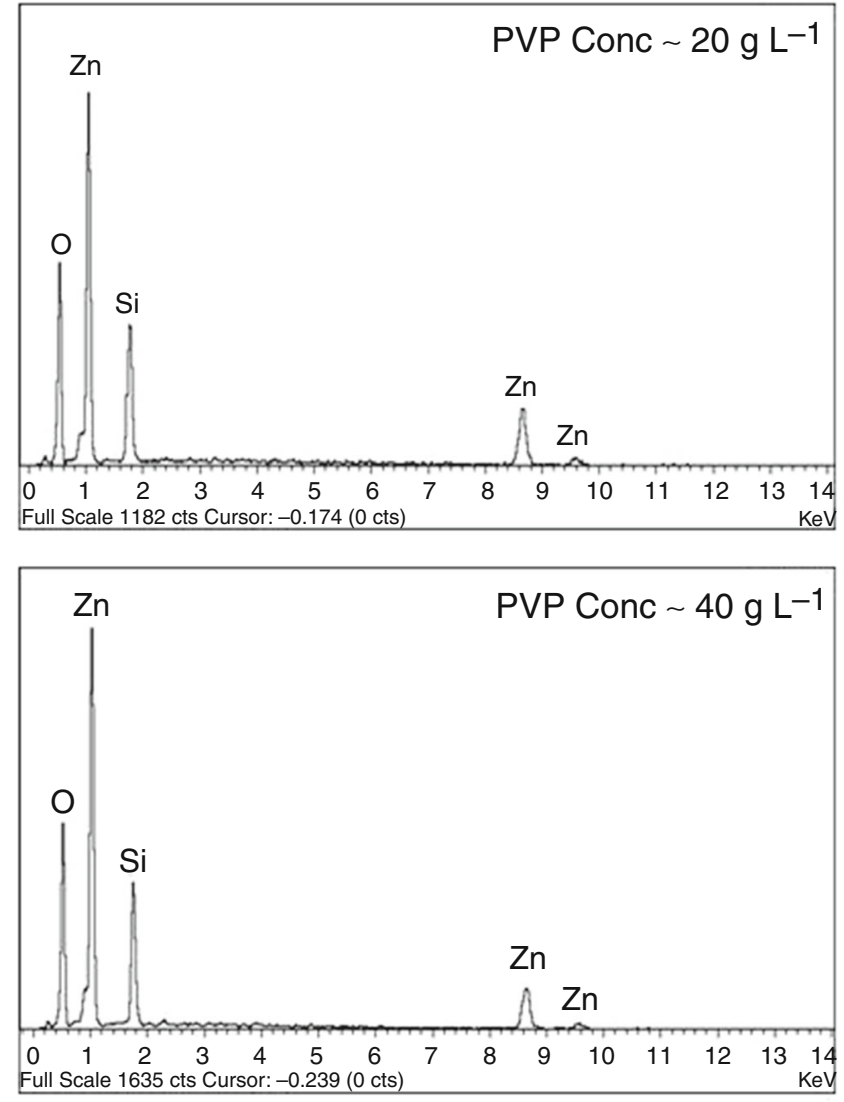
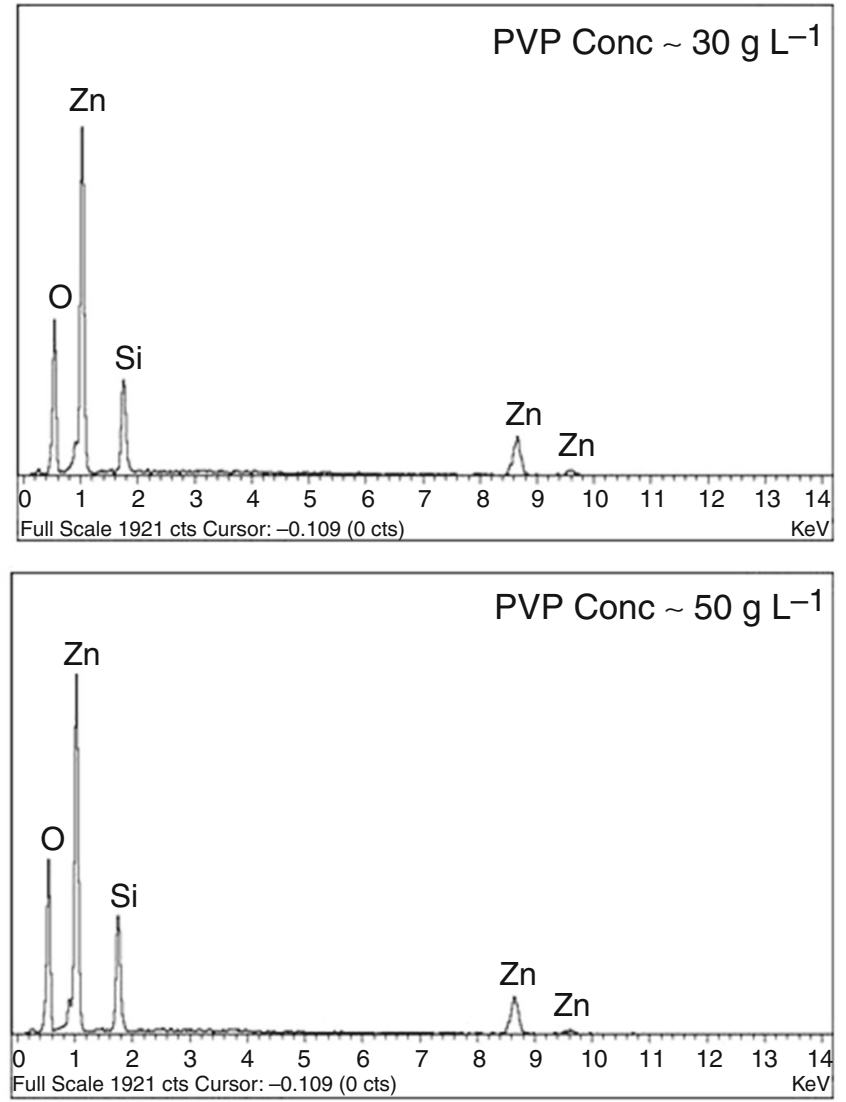

Fig. 8 EDX spectrum of willemite nanoparticles calcined $900{ }^{\circ} \mathrm{C}$, over a range of PVP amounts

PVP concentration (40 and $50 \mathrm{~g} \mathrm{~L}^{-1}$ ). These are attributed to the fact that PVP at a higher concentration is enough to restrict the nucleation growth of the NPs, thereby reducing the NPs agglomeration and aggregation [48, 49]. The uniformity of the willemite NPs distribution shown in Fig. 9 is less at the 20 and $30 \mathrm{~g} \mathrm{~L}^{-1}$ PVP concentration due to the inadequate polymeric chain to cap the material and hinder the nucleation growth [59]. Nevertheless, Fig. 10 and Table 3 present the average particle dimensions at several PVP concentrations which are estimated to be reduced from $36.7 \mathrm{~nm}$ at $20 \mathrm{~g} \mathrm{~L}^{-1}$ to $23.8 \mathrm{~nm}$ at $50 \mathrm{~g} \mathrm{~L}^{-1}$ measured using the Image $\mathrm{J}$ software. The SAED was 


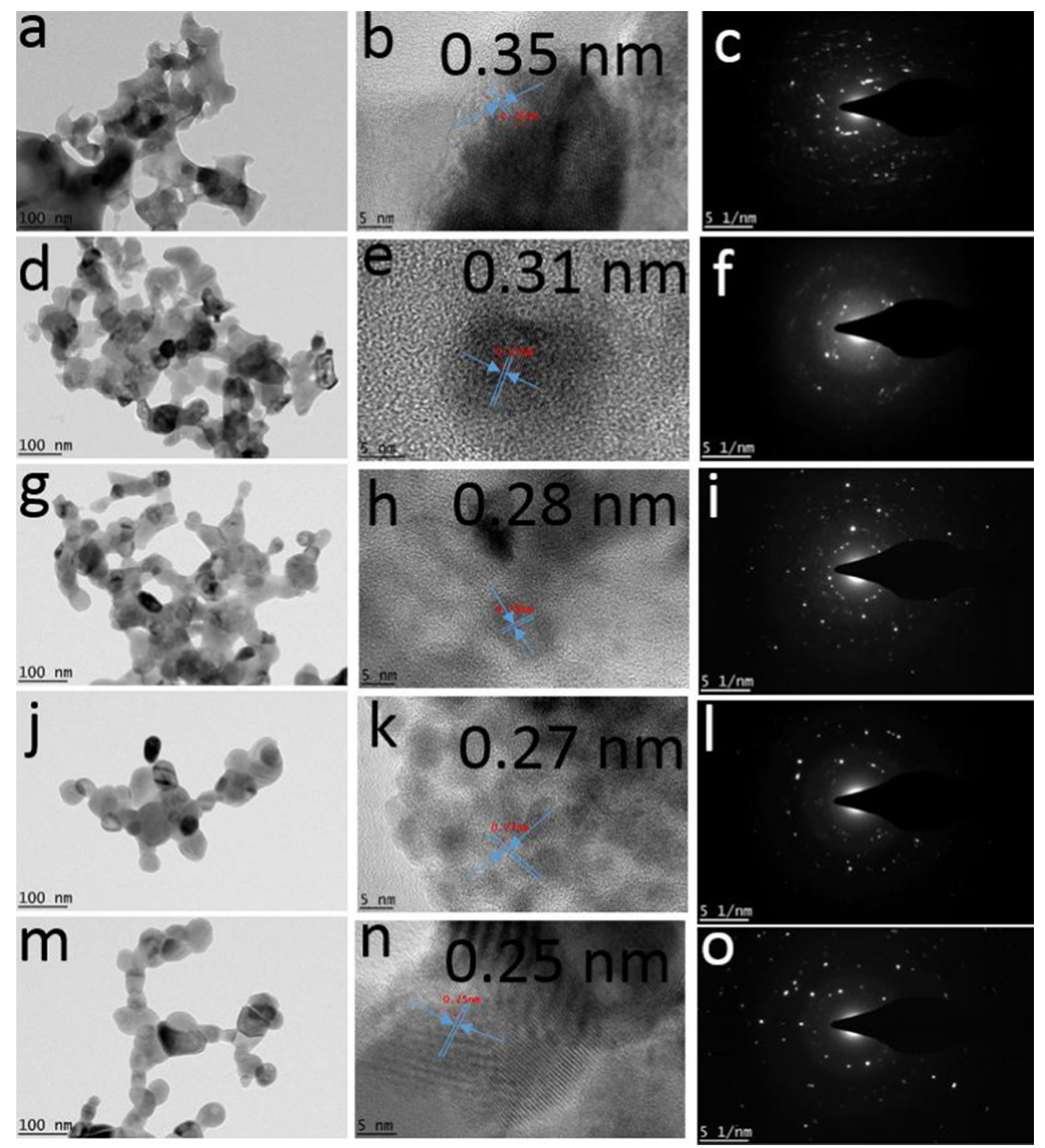

Fig. 9 HR-TEM images of willemite NPs calcined at $900{ }^{\circ} \mathrm{C}$ over a range of PVP amounts a-c $0.0 \mathrm{~g} \mathrm{~L}^{-1}, \mathbf{d}-\mathbf{f} 20 \mathrm{~g} \mathrm{~L}^{-1}, \mathbf{g}-\mathbf{i} 30 \mathrm{~g} \mathrm{~L}-1$, jl $40 \mathrm{~g} \mathrm{~L}^{-1}, \mathbf{m}-\mathbf{0} 50 \mathrm{~g} \mathrm{~L}^{-1}$

likewise conducted on the samples to confirm the polycrystalline nanostructure of the prepared willemite NPs. In addition, the findings also revealed that the space between the two adjacent planes, $d$, of the willemite NPs shown in Fig. 9, is reducing in the range $0.35-0.25 \mathrm{~nm}$ with an increasing concentration of PVP from $0-50 \mathrm{~g} \mathrm{~L}^{-1}$. This is in conformity with the outcomes of the XRD analysis of this work. The NPs were near hexagonal in shape, similar to those reported by previous researchers [40, 61, 62].

\section{Optical analysis}

\section{UV-Vis study}

The influence of various concentrations of PVP calcined at temperatures between 800 and $1000{ }^{\circ} \mathrm{C}$ on the optical properties of willemite NPs had also been examined. The absorbance spectra values, presented in Fig. 11, are studied within the wavelength of $200-800 \mathrm{~nm}$ at a normal room temperature, for several PVP concentrations covering 20-50 $\mathrm{g} \mathrm{L}^{-1}$. The material reveals a maxima absorption edge of $369 \mathrm{~nm}$ for all samples. This is attributed to the transition of an electron from the valence band to the 

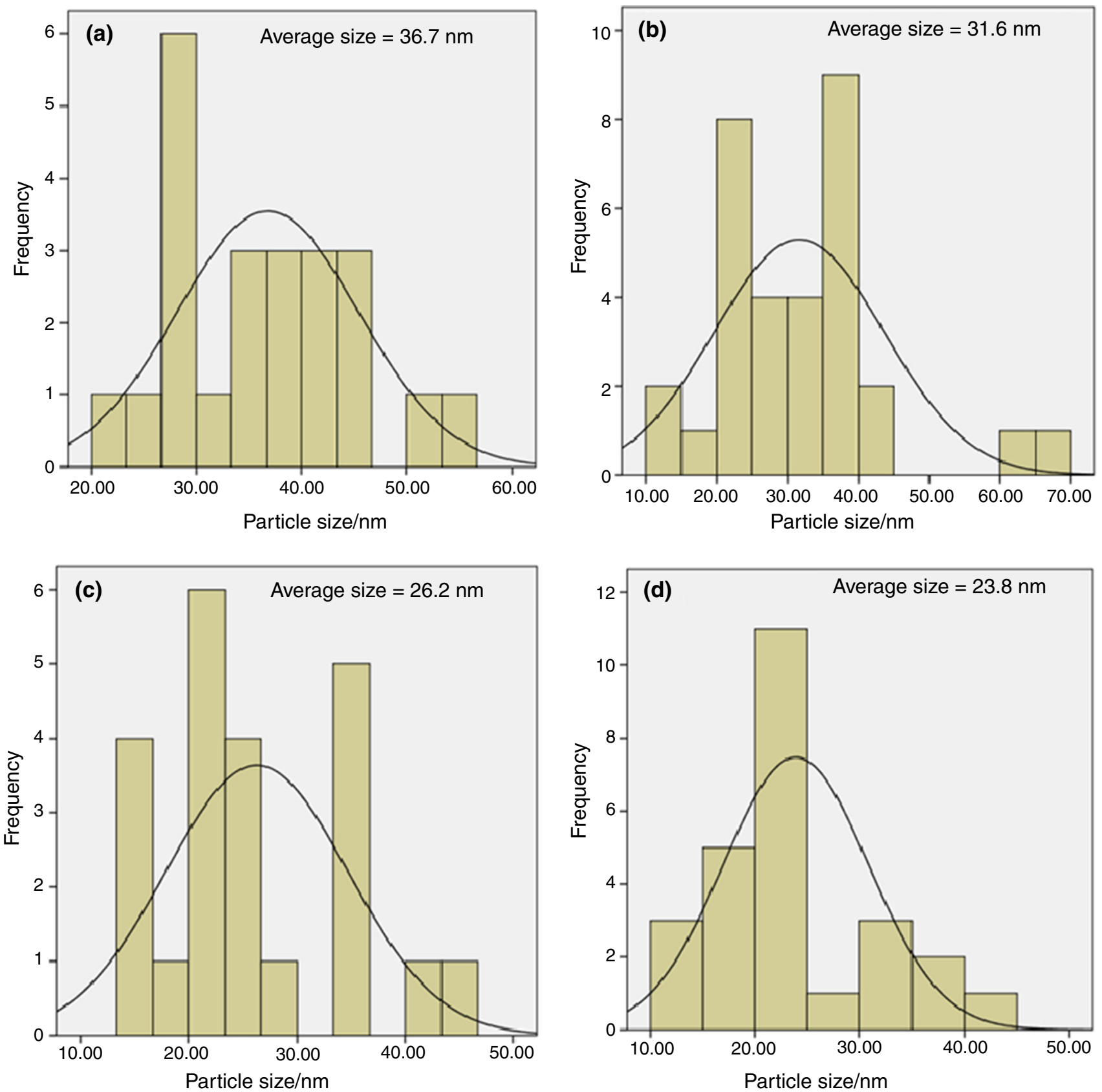

Fig. 10 Particle size distribution of willemite NPs calcined at $900{ }^{\circ} \mathrm{C}$ at PVP different concentration: a $20 \mathrm{~g} \mathrm{~L}^{-1}$, b $30 \mathrm{~g} \mathrm{~L}^{-1}$, c $40 \mathrm{~g} \mathrm{~L}^{-1}$ and d $50 \mathrm{~g} \mathrm{~L}^{-1}$

conduction band, and it decreases with the increase in the calcination temperature $[50,63]$. The intensity of the spectrum is less at a high calcination temperature, and it tends to shift to lower the wavelength in the UV region as the temperature increases. The shift to a lower wavelength may be attributed to the relatively larger band gap $(5.37 \mathrm{eV})$ of willemite NPs [50].

The experimental optical band gap values of the willemite NPs produced at optimum temperature of $900{ }^{\circ} \mathrm{C}$ with several PVP concentration of $\left(20-50 \mathrm{~g} \mathrm{~L}^{-1}\right)$ was evaluated based on the relationship between absorbance and extinction coefficient in the following equation;

$k=\frac{\alpha \lambda}{4 \pi}$

where $\mathrm{k}$ is known as the extinction coefficient, $\pi=3.14, \alpha$ and $\lambda$ are the absorbance and the wavelength (nm), respectively. A graph of extinction coefficient as a function of photon energy is plotted as shown in Fig. 12; the linear region of the graph is extrapolated as the extinction 

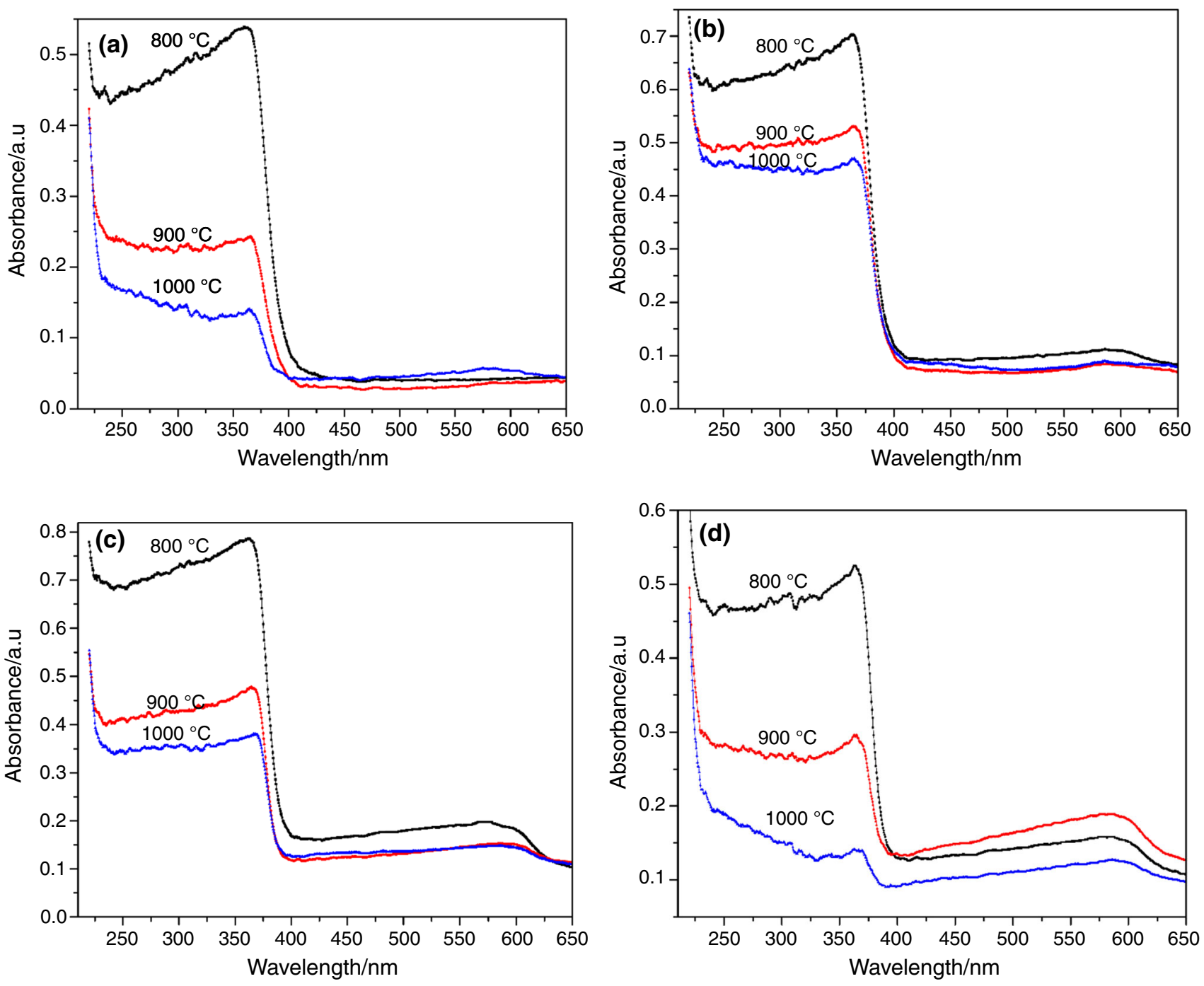

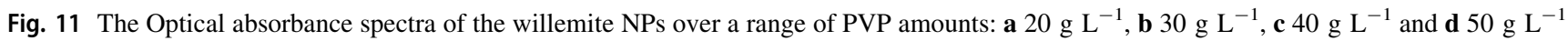

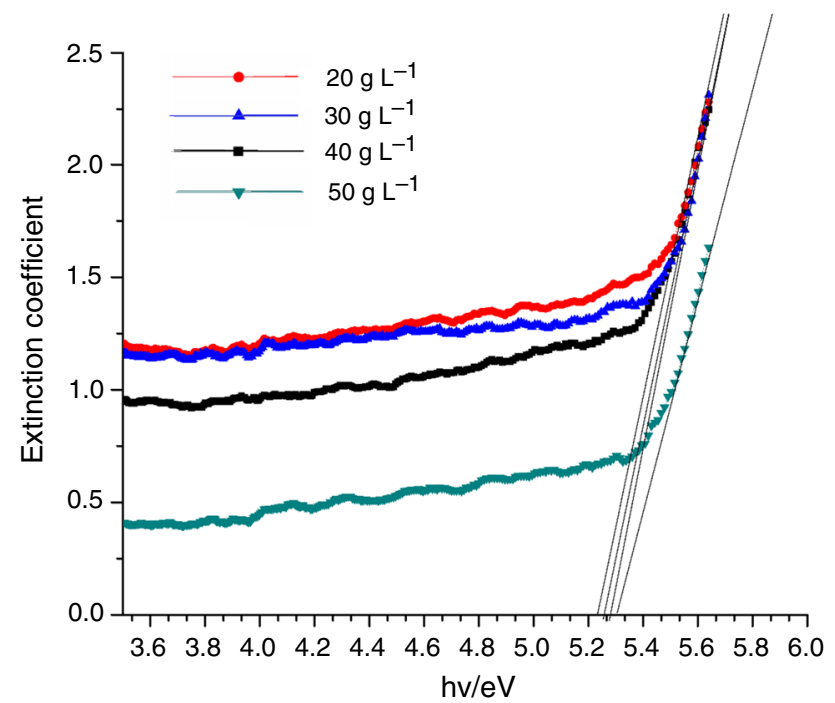

Fig. 12 Plot of extinction coefficient versus photon energy $(h v)$ for willemite NPs calcined at $900{ }^{\circ} \mathrm{C}$ for various PVP amounts

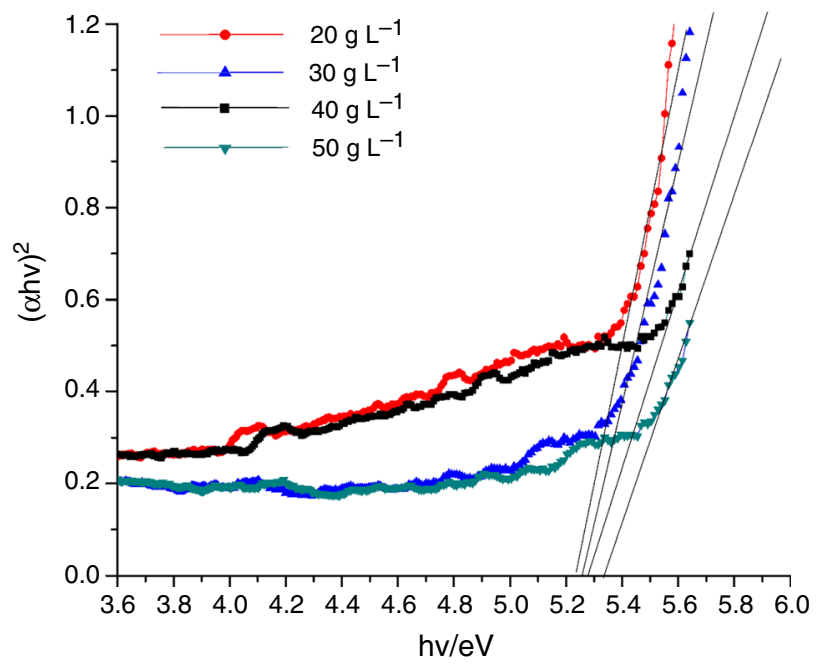

Fig. 13 Plot of $(\alpha h v)^{2}$ as a function of photon energy $(h v)$ for willemite NPs calcined at $900{ }^{\circ} \mathrm{C}$ for various PVP amounts 
Table 5 Summary of the impact different PVP amounts on the optical band gap of the willemite NPs synthesized at the calcination temperature of $900{ }^{\circ} \mathrm{C}$

\begin{tabular}{llllll}
\hline $\begin{array}{l}\text { Amounts of } \\
\mathrm{PVP} / \mathrm{g} \mathrm{L}^{-1}\end{array}$ & $\begin{array}{l}E_{\mathrm{g}} \\
\text { experimental } \\
\mathrm{eV}\end{array}$ & $\begin{array}{l}E_{\mathrm{g}} \text { direct allowed } \\
\text { transition } n=1 / 2 \mathrm{eV}\end{array}$ & $\begin{array}{l}E_{\mathrm{g}} \text { direct forbidden } \\
\text { transition } n=3 / 2 \mathrm{eV}\end{array}$ & $\begin{array}{l}E_{\mathrm{g}} \text { indirect allowed } \\
\text { transition } n=2 \mathrm{eV}\end{array}$ & $\begin{array}{l}E_{\mathrm{g}} \text { indirect forbidden } \\
\text { transition } n=3 \mathrm{eV}\end{array}$ \\
\hline 20.0 & $5.24 \pm 0.04$ & $5.23 \pm 0.04$ & $5.42 \pm 0.04$ & $5.26 \pm 0.04$ & $5.32 \pm 0.04$ \\
30.0 & $5.26 \pm 0.04$ & $5.24 \pm 0.04$ & $5.36 \pm 0.04$ & $5.15 \pm 0.04$ & $5.24 \pm 0.04$ \\
40.0 & $5.28 \pm 0.04$ & $5.26 \pm 0.04$ & $5.48 \pm 0.04$ & $5.14 \pm 0.04$ & $5.36 \pm 0.04$ \\
50.0 & $5.32 \pm 0.04$ & $5.28 \pm 0.04$ & $5.16 \pm 0.04$ & $5.11 \pm 0.04$ & $5.24 \pm 0.04$ \\
\hline
\end{tabular}

coefficient tends to be zero. The energy values derived from the extinction coefficient are increased from $5.24 \mathrm{eV}$ at $20 \mathrm{~g} \mathrm{~L}^{-1}$ of PVP concentration to $5.32 \mathrm{eV}$ at $50 \mathrm{~g} \mathrm{~L}^{-1}$ of PVP concentration. The increase in the optical band gap was due to particle size reduction of the material when subjected to the variation of PVP concentration (20$50 \mathrm{~g} \mathrm{~L}^{-1}$ ). This is evidenced by XRD and TEM analyses reported in this work. It is thought that as the particle size increases, the number of atoms that form a particle increases as well, thus render the valence and conduction electrons more attractive to the ions core of the particles and therefore decreasing the band gap of the particles. In order to determine the type of transition in the material, the experimental values are compared with the band gap energy derived from Mott and Davis Model [64] shown in Eq. (3).

$(\alpha h v)^{1 / \mathrm{n}}=A\left(h v-E_{\mathrm{g}}\right)$

where $A$ is a constant, the photon energy is denoted by $h v$ and $E_{\mathrm{g}}$ is the optical energy band presented in Fig. 13. The parameter $\mathrm{n}$ is an exponent that indicates the type of the optical band gap energy (direct or indirect). The values of $n$ for allowed direct, allowed indirect, forbidden direct and forbidden indirect transitions are $1 / 2,2,3 / 2$ and 3 ,

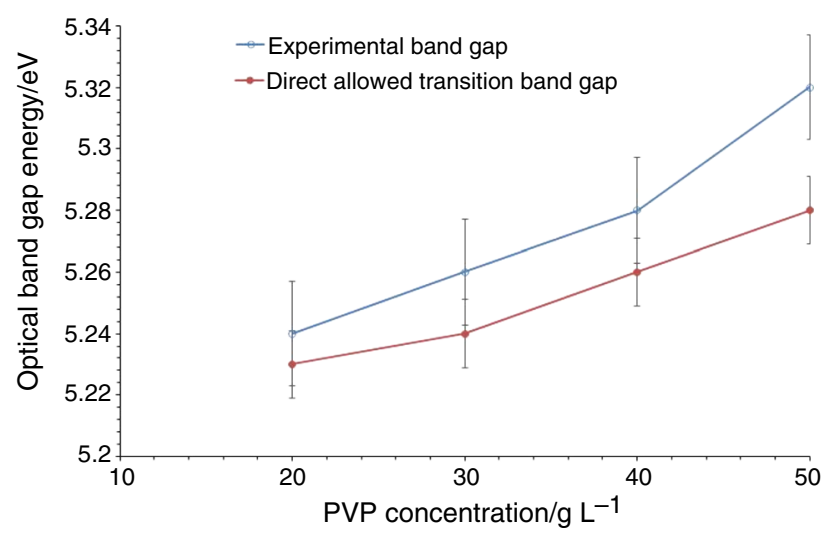

Fig. 14 PVP Compositional dependence of experimental optical band gap and optical band gap from Mott and Davis Model for $n=1 / 2$ transition respectively. The characteristics $(\alpha h v)^{1 / \mathrm{n}}$ is plotted as a function of $h v$ values, where the optical band gap of the willemite NPs is obtained by the extrapolation of the linear region to where $(\alpha h v)^{1 / n}$ tends to be zero. Comparing the band gap value from the experimental curve with the optical band gap obtained using Mott and Davis model for different values of $\mathrm{n}$ shown in Table 5 and Fig. 14, a good agreement with the band gap values for $n=1 / 2$ are achieved. Therefore, it can be concluded that the optical band gap were due to the direct allowed transition. The band gap values obtained in this study are in agreement with those reported by other researchers [50, 56, 65-67].

\section{Photoluminescence study}

Photoluminescence analysis (PL) was used to study the excitation and emission of the energy level of willemite NPs. The PL spectrum of the willemite NPs was recorded to (or "intending to") apprehend the effect of the PVP on the emission properties of the sample. This was achieved using a PL spectrometer, and the generated peaks in the spectra exhibit the energy levels within the materials. The effect of various PVP concentrations $\left(20-50 \mathrm{~g} \mathrm{~mL}^{-1}\right)$, as well as an increase in the calcination temperature within the range of $800-1000{ }^{\circ} \mathrm{C}$, was considered. In this light, Fig. 15 shows the emission spectra of the synthesized willemite NPs using an excitation wavelength of $350 \mathrm{~nm}$ conducted at normal room temperature. Al-Hada et al. [59] reported that for a metal oxide semiconductor, there is supposed to be an existing range of prospective emissions attributed to impurities or crystal defects, like exciton band to neutral donor, band-edge recombination, donor to acceptor recombination, exciton band to neutral acceptor, free excitonic transition, excitation from interstitial $\mathrm{X}$ to conduction band, interstitial $\mathrm{M}$ to valence band, excitation from $M$ vacancy to the valence band, and $X$ vacancy to the valence band. The emission positioned roughly at $485 \mathrm{~nm}$ in the blue region is assumed to be due to zinc interstitial and is often referred to as the blue emission [50,62, 68]. The green emission observed at 530 and $543 \mathrm{~nm}$ is because 

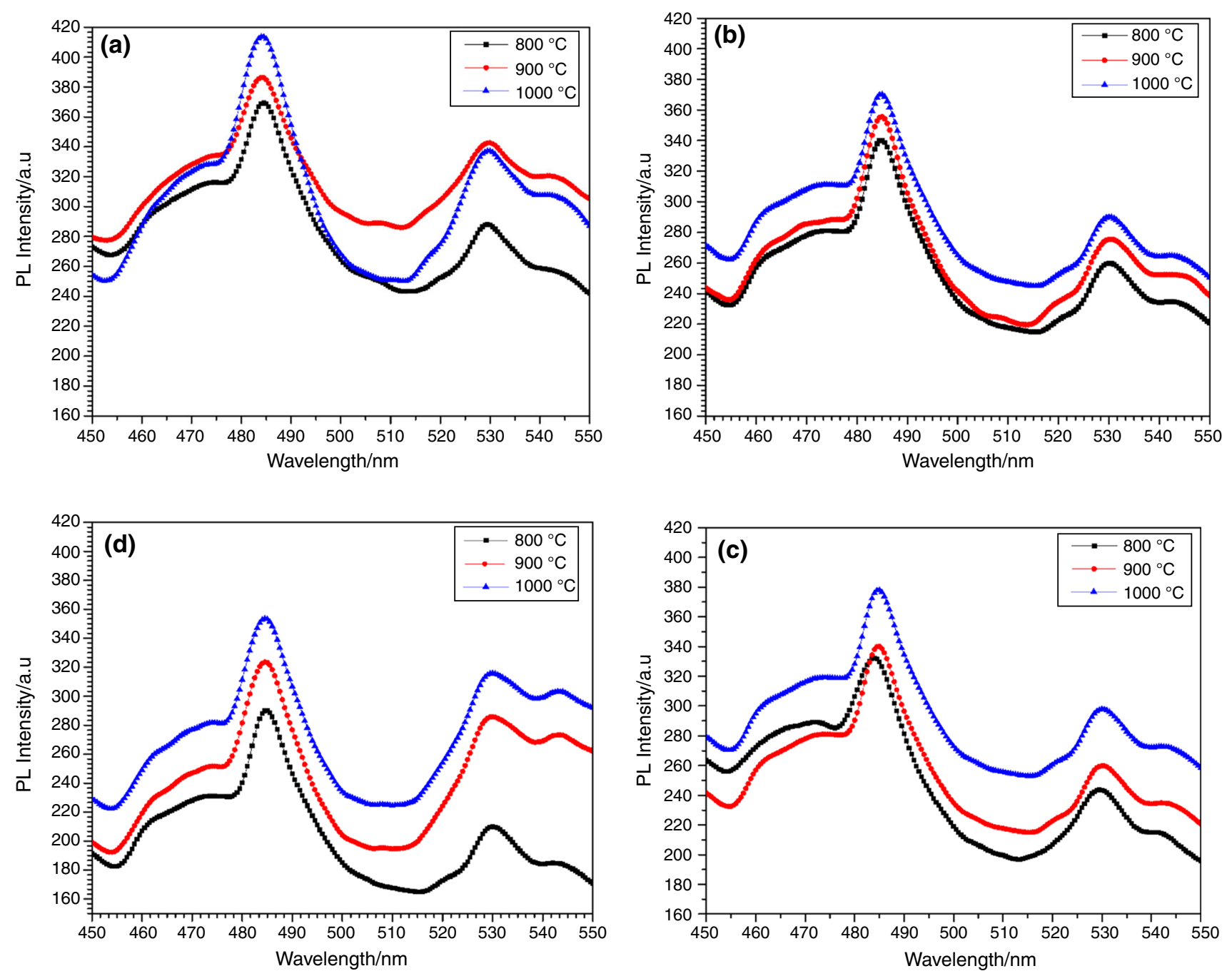

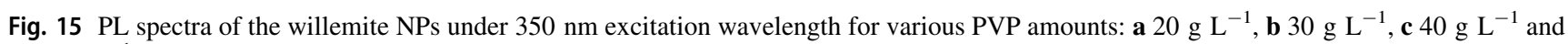
d $50 \mathrm{~g} \mathrm{~L}^{-1}$

of the transition between the valence and conduction. As can be seen in Fig. 15, the intensity of the emission is affected by the increase in the calcination temperature, for all the PVP concentration. Higher PL intensity can be achieved as a result of the improved crystal quality [69]. In this light, calcination process is an effective way to improve the emission intensities of phosphor due to low surface defects and improved crystallinity [70-72]. The surface area is greatly reduced when the crystallite size is increased. As a result of that, the phosphor would show a vast improvement in the PL intensity [73, 74] attributed three phenomena responsible for the enhancement in emission intensity in $\mathrm{ZnO}$-loaded $\mathrm{SiO}_{2}$ matrix to surface passivation of $\mathrm{ZnO}$ NPs, the formation of interface states between $\mathrm{ZnO}$ and $\mathrm{SiO}_{2}$, as well as excitation process in the $\mathrm{SiO}_{2}$. While linking the influence of several PVP amounts, it is evident that along with a decrease in particle size, higher amounts of PVP result in a reduction in intensity of the emission. This is in good agreement with the findings of other researchers on the effects of PVP on optical and structural properties of metal oxide NPs [10, 11].

\section{Formation mechanism}

The proposed schematic diagram of the impact of PVP on the particle size, morphology and uniformity of willemite NPs is illustrated in Scheme 1. Primarily, the main task of PVP is to stabilize the complex metallic salts. This is achievable through steric and electrostatic stabilization of the amide groups of the pyrrolidone rings and the methylene groups. The mixing process of the substance enabled the metallic ions to be subdued and eventually confined to the amine group by ionic-dipole interactions in the polymeric chains. Accordingly, the metallic cations tend to be immobile in the polymer cavity as the water is evaporated by drying the mixture. The organic matters present in the 


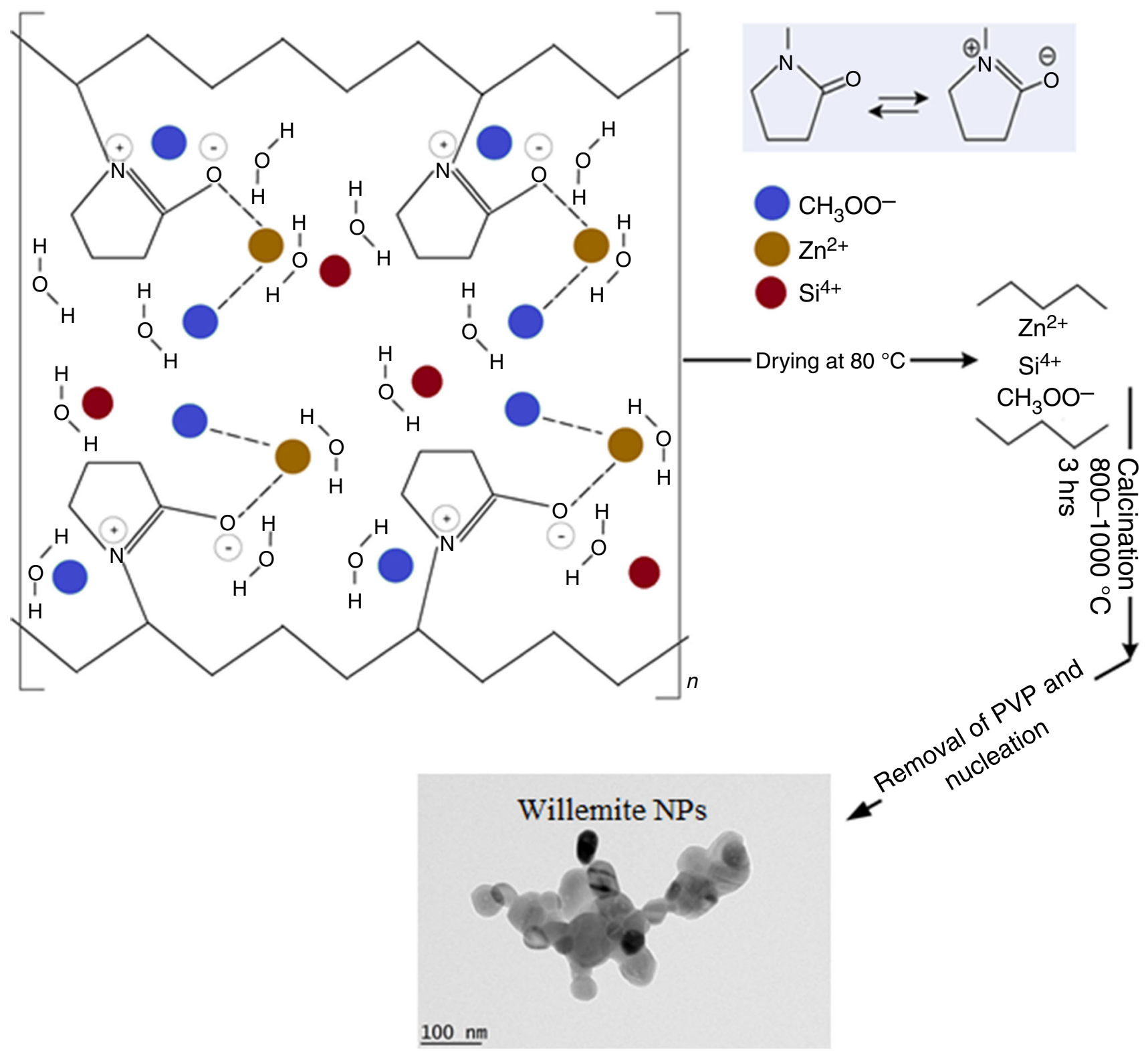

Scheme 1 A proposed mechanism of interaction for metal ions and PVP in the formation of willemite NPs

sample are decomposed and converted into gases like carbon monoxide, carbon dioxide or nitrogen caused by the calcination process. Thus, the polymer content and unwanted anions are entirely removed and the willemite phase is formed.

\section{Conclusions}

This study emphasized the influence and task of PVP in the synthesis of willemite NPs encompassing simple polymer synthesis techniques. The sample prepared in the absence of PVP revealed uneven particle distribution, high agglomeration and unable to produce single $\alpha$-willemite phase. The XRD results revealed the amorphous state of the samples before calcination at room temperature and exhibited a crystal phase of willemite after calcination between 800 and $1000{ }^{\circ} \mathrm{C}$. In accordance with XRD, FESEM and HR-TEM results, the crystallite size, and particles size of the willemite NPs decreased with increasing PVP concentration from 36.7 to $23.8 \mathrm{~nm}$. Both Raman and FTIR spectra confirmed the presence of organic source in the samples before heat treatment and crystallization of samples after the calcination process. The optimum PVP concentration in this study based on the FTIR results was found to be $40 \mathrm{~g} \mathrm{~L}^{-1}$ calcined at $900{ }^{\circ} \mathrm{C}$. Thus, this is the minimum concentration at which the NPs produced stayed pure with homogenous distribution of 
shapes. The presence of $\mathrm{Zn}, \mathrm{Si}$, and $\mathrm{O}$ in all the samples after calcination was confirmed by the EDX analysis, which implied that there were no elemental losses in the system. The optical band gap of the willemite NPs expanded, from 5.24 to $5.32 \mathrm{eV}$ alongside rising in PVP concentration. The PL emission spectra exhibit a blue emission at $485 \mathrm{~nm}$ due to zinc interstitial, and the intensity of the emission is affected by the increase in the calcination temperature. For all the PVP concentrations, the emission was affected due to the reduction in the particles size of the willemite, causing the decrease in the emission spectra. The polymer thermal treatment method synthesis has proven to be one of the simplest and environmentally friendly methods to fabricate willemite NPs due to the lack of harmful chemicals and toxic by-product effluents. Finally, the findings in this study provides a new pathway to comprehend the influence of PVP concentrations on the structural and optical properties of the fabricated willemite semiconductor NPs and can justify the use of these novel materials as a potential candidate for optoelectronic applications.

Acknowledgements The authors wish to gratefully acknowledge the financial support for this study from the Malaysian Ministry of Higher Education (MOHE) Grant Numbers 9531300 and 5526200, Universiti Putra Malaysia (MY) International Graduate Research Fellow UPM/ SPS/GS46148.

\section{Compliance with ethical standards}

Conflict of interest On behalf of all authors, the corresponding author states that there is no conflict of interest.

Open Access This article is distributed under the terms of the Creative Commons Attribution 4.0 International License (http://creative commons.org/licenses/by/4.0/), which permits unrestricted use, distribution, and reproduction in any medium, provided you give appropriate credit to the original author(s) and the source, provide a link to the Creative Commons license, and indicate if changes were made.

\section{References}

1. Ajayan PM, Schadler LS, Braun PV. Nanocomposite science and technology. Weinheim: WILEY-VCH Verlag GmbH \& Co. $\mathrm{KGaA} ; 2006$.

2. Jordan J, Jacob KI, Tannenbaum R, Sharaf MA, Jasiuk I. Experimental trends in polymer nanocomposites-a review. Mater Sci Eng A. 2005;393:1-11.

3. Berta M, Lindsay C, Pans G, Camino G. Effect of chemical structure on combustion and thermal behaviour of polyurethane elastomer layered silicate nanocomposites. Polym Degrad Stab. 2006;91:1179-91.

4. Li S, Yu X, Lu R, Liu P, Cai W. Thermal kinetics of self-aggregation and self-assembly of $\mathrm{Ag}$ nanoparticles with different capping agents. J Therm Anal Calorim. 2015;12:855-60.

5. Censi R, Gigliobianco MR, Malaj L, Di Martino P. Effect of poly (vinylpyrrolidone) or sodium alginate on the stability of the amorphous form of nimesulide. $\mathrm{J}$ Therm Anal Calorim. 2016;123:2415-25.

6. Zhang A, Nan Z. In situ microcalorimetric investigation on effects of surfactants on cluster-shaped Ni-doped $\mathrm{Fe}_{3} \mathrm{O}_{4}$ formation. J Therm Anal Calorim. 2018;132:859-68.

7. Kumar AP, Depan D, Tomer NS, Singh RP. Nanoscale particles for polymer degradation and stabilization-trends and future perspectives. Prog Polym Sci. 2009;34:479-515.

8. Al-Hada NM, Saion EB, Shaari AH, Kamarudin MA, Flaifel MH, Ahmad SH, Gene A. A facile thermal-treatment route to synthesize the semiconductor $\mathrm{CdO}$ nanoparticles and effect of calcination. Mater Sci Semicond Process. 2014;24:60-466.

9. Alibe IM, Matori KA, Saion E, Ali AM, Zaid MHM. The influence of calcination temperature on structural and optical properties of $\mathrm{ZnO}$ nanoparticles via simple polymer synthesis route. Sci Sinter. 2017;49:263-75.

10. Baqer AA, Matori KA, Al-Hada NM, Shaari AH, Saion E, Chyi JLY. Effect of polyvinylpyrrolidone on cerium oxide nanoparticle characteristics prepared by a facile heat treatment technique. Results Phys. 2017;7:611-9.

11. Kamari HM, Al-Hada NM, Saion E, Shaari AH, Talib ZA, Flaifel $\mathrm{MH}$, Ahmed AAA. Calcined solution-based PVP influence on $\mathrm{ZnO}$ semiconductor nanoparticle properties. Crystals. 2017;7:2. https://doi.org/10.3390/cryst7020002.

12. Khanna PK, Kumar A, Kshirsagar A, Hiragond C. CdSe-PVP QDs for degradation of methylene blue via photocatalytic oxidative cleavage under mild visible light. J Nanosci Nanotechnol. 2018;18:143-55.

13. Antonietti M, Göltner C. Superstructures of functional colloids: chemistry on the nanometer scale. Angew Chem Int Ed. 1997;36:910-28.

14. Schmid G, Chi LF. Metal clusters and colloids. Adv Mater. 1998;10:515-26.

15. Reetz MT, Helbig W. Size-selective synthesis of nanostructured transition metal clusters. J Chem Soc. 1994;116:7401-2.

16. Wan J, Chen X, Wang Z, Mu L, Qian Y. One-dimensional ricelike Mn-doped $\mathrm{Zn}_{2} \mathrm{SiO}_{4}$ : preparation, characterization, luminescent properties and its stability. J Cryst Growth. 2005;280:239-43.

17. Yu X, Wang Y. Synthesis and VUV spectral properties of nanoscaled $\mathrm{Zn}_{2} \mathrm{SiO}_{4}: \mathrm{Mn}^{2+}$ green phosphor. J Phys Chem Solids. 2009;70:1146-9.

18. Lee S, Jeon B, Kang T, Lee W, Malik AM, Park S, Lim J, Park B, Jeong Y. Optical and electrical properties of $\mathrm{Zn}_{2} \mathrm{SiO}_{4}: \mathrm{Mn}^{2+}$ powder electroluminescent device. J Lumin. 2018;196:290-3.

19. Romanov SG, Fokin AV, De La Rue RM. Eu ${ }^{3+}$ emission in an anisotropic photonic band gap environment. Appl Phys Lett. 2000;76:1656-8.

20. Tarafder A, Molla AR, Karmakar B. Advanced glass-ceramic nanocomposites for structural, photonic, and optoelectronic applications. J Glass Nanocompos. 2016. https://doi.org/10.1016/ b978-0-323-39309-6.00013-4.

21. Veremeichik TF, Zharikov EV, Subbotin KA. New laser crystals of complex oxides doped with ions of $d$ elements with variable valence and different structural localization. Rev Crystallogr Rep. 2003;48:974-88.

22. Vitkin VV, Dymshits OS, Polyakov VM, Zhilin AA, Shemchuk DV, Krylov AA, Uskov AV, Mak AA, Kovalev AV. Pulse-burst Er: glass laser. Solid State Lasers XXVI Technol Dev. 2017;1008224:1-11. https://doi.org/10.1117/12.2252107.

23. Zaid MH, Matori KA, Ab Aziz SH, Kamari HM, Wahab ZA, Effendy N, Alibe IM. Comprehensive study on compositional dependence of optical band gap in zinc soda lime silica glass system for optoelectronic applications. J Non Cryst Solids. 2016;449:107-12. 
24. Effendy N, Wahab ZA, Abdul Aziz SH, Matori KA, Zaid MH, Rashid SS. Characterization and optical properties of erbium oxide doped $\mathrm{ZnO}-\mathrm{SLS}$ glass for potential optical and optoelectronic materials. Mater Exp. 2017;7:59-65.

25. Wang X, Huang H, Liu B, Liang B, Zhang C, Ji Q, Chen D, Shen G. Shape evolution and applications in water purification: the case of CVD-grown $\mathrm{Zn}_{2} \mathrm{SiO}_{4}$ straw-bundles. J Mater Chem. 2012;22:5330-5.

26. Dai P, Sun YQ, Bao ZW, Zhu J, Wu MZ. Optical and adsorption properties of mesoporous $\mathrm{SiO}_{2} / \mathrm{Zn}_{2} \mathrm{SiO}_{4}: \mathrm{Eu}^{3+}$ hollow nanospheres. Micro Nano Lett. 2017;12:248-51.

27. Omri K, Lemine OM, El Mir L. Mn doped zinc silicate nanophosphor with bifunctionality of green-yellow emission and magnetic properties. Ceram Int. 2017;43:6585-91.

28. Babu BC, Wang GG, Yan B, Yang Q, Baker AP. Effects of $\mathrm{Cr}^{3+}$ addition on the structure and optical properties of $\alpha-\mathrm{Zn}_{2} \mathrm{SiO}_{4}$ synthesized by sol-gel method. Ceram Int. 2018;44:938-46.

29. Zaid MH, Matori KA, Aziz SH, Kamari HM, Wahab ZA, Fen YW, Alibe IM. Synthesis and characterization of low cost willemite based glass-ceramic for optoelectronic applications. J Mater Sci Mater Electron. 2016;7:11158-67.

30. Onufrieva TA, Krasnenko TI, Zaitseva NA, Samigullina RF, Enyashin AN, Baklanova IV, Tyutyunnik AP. Concentration growth of luminescence intensity of phosphor $\mathrm{Zn} 2-2 \mathrm{xMn} 2 \mathrm{xSiO} 4$ ( $x \leq 0.13)$ : crystal-chemical and quantum-mechanical justification. Mater Res Bull. 2018;97:182-8.

31. Gasek K, Partyka J, Gajek M, Panna W. Characteristic of synthesis and transformations of hardystonite in willemite glasscrystalline glaze based on thermal analysis. J Therm Anal Calorim. 2016;125:1135-42.

32. Rivera-Enríquez CE, Fernández-Osorio A. Luminescence properties of $\alpha$-and $\beta-\mathrm{Zn}_{2} \mathrm{SiO}_{4}$ : Mn nanoparticles prepared by a coprecipitation method. J Alloys Compd. 2016;688:775-82.

33. Kang YC, Park SB. $\mathrm{Zn}_{2} \mathrm{SiO}_{4}$ : Mn phosphor particles prepared by spray pyrolysis using a filter expansion aerosol generator. Mater Res Bull. 2000;35:1143-51.

34. Kang Z, Wei L, Huiping T, Guangtong X, Lei W, Hua X. Study on $\mathrm{Zn}_{2} \mathrm{SiO}_{4}$ formation kinetics and activity stability of desulfurization sorbent. China Pet Process PE. 2015;17:6-15.

35. Samigullina RF, Tyutyunnik AP, Gracheva IN, Krasnenko TI, Zaitseva NA, Onufrieva TA. Hydrothermal synthesis of $\alpha-\mathrm{Zn}_{2}$ $\mathrm{SiO}_{4}$ : V phosphor, determination of oxidation states and structural localization of vanadium ions. Mater Res Bull. 2017;87:27-33.

36. Zaitseva NA, Krasnenko TI, Onufrieva TA, Samigullina RF. Hydrothermal synthesis and microstructure of $\alpha-\mathrm{Zn}_{2} \mathrm{SiO}_{4}: \mathrm{V}$ crystal phosphor. Russ J Org Chem. 2017;s62:168-71.

37. Toyama S, Takesue M, Aida TM, Watanabe M, Smith RL Jr. Easy emission-color-control of Mn-doped zinc silicate phosphor by use of $\mathrm{pH}$ and supercritical water conditions. J Supercrit Fluids. 2015;98:65-9.

38. Shibuki K, Takesue M, Aida TM, Watanabe M, Hayashi H, Smith RL Jr. Continuous synthesis of $\mathrm{Zn}_{2} \mathrm{SiO}_{4}: \mathrm{Mn}^{2+}$ fine particles in supercritical water at temperatures of $400-500{ }^{\circ} \mathrm{C}$ and pressures of 30-35 MPa. J Supercrit Fluids. 2010;54:266-71.

39. Takeshita S, Honda J, Isobe T, Sawayama T, Niikura S. Sizetunable solvothermal synthesis of $\mathrm{Zn}_{2} \mathrm{GeO}_{4}: \mathrm{Mn}^{2+}$ nanophosphor in water/diethylene glycol system. Cryst Growth Des. 2010;10:4494-500.

40. Masjedi-Arani M, Salavati-Niasari M. A simple sonochemical approach for synthesis and characterization of $\mathrm{Zn}_{2} \mathrm{SiO}_{4}$ nanostructures. Ultrason Sonochem. 2016;29:226-35.

41. Rasdi NM, Fen YW, Omar NA, Zaid MH. Effects of cobalt doping on structural, morphological, and optical properties of $\mathrm{Zn}_{2} \mathrm{SiO}_{4}$ nanophosphors prepared by sol-gel method. Results Phys. 2017;7:3820-5.
42. Babu BC, Buddhudu S. Dielectric properties of willemite $\mathrm{Zn}_{2}$ $\mathrm{SiO}_{4}$ nano powders by sol-gel method. Phys Proc. 2013;49:128-36.

43. Diao CC, Yang CF, Wang RL, Lin JJ, Fu MY. Prepare high efficiency $\mathrm{Mn}^{2+}$-doped $\mathrm{Zn}_{2} \mathrm{SiO}_{4}$ green phosphors in air using nano-particles. J Lumin. 2011;131:915-20.

44. Zhang S, Lu M, Li Y, Sun F, Yang J, Wang S. Synthesis and electrochemical properties of $\mathrm{Zn}_{2} \mathrm{SiO}_{4}$ nano/mesorods. Mater Lett. 2013;100:89-92.

45. An JS, Noh JH, Cho IS, Roh HS, Kim JY, Han HS, Hong KS. Tailoring the morphology and structure of nanosized $\mathrm{Zn}_{2} \mathrm{SiO}_{4}$ :$\mathrm{Mn}^{2+}$ phosphors using the hydrothermal method and their luminescence properties. J Phys Chem C. 2010;114:10330-5.

46. Xu G-Q, Liu J-Q, Zheng Z-X, Wu Y-C. Low-temperature synthesis and luminescence properties of $\left.\left.\mathrm{Zn}_{2}\right) \mathrm{SiO}_{4}\right): \mathrm{Mn}^{(2+)}$ phosphors. Chin J Lum. 2011;32:550-4.

47. Al-Hada NM, Saion EB, Shaari AH, Kamarudin MA, Flaifel MH, Ahmad SH, Gene SA. A facile thermal-treatment route to synthesize $\mathrm{ZnO}$ nanosheets and effect of calcination temperature. PLoS ONE. 2014;9:e103134. https://doi.org/10.1371/journal. pone. 0103134 .

48. Alibe IM, Matori KA, Saion E, Alibe AM, Zaid MH, Engku EG. A facile synthesis of amorphous silica nanoparticles by simple thermal treatment route. Dig J Nanomater Biostruct. 2016;11:1155-64.

49. Leśniak M, Gajek M, Partyka J, Sitarz M. Thermal characterisation of raw aluminosilicate glazes in $\mathrm{SiO}_{2}-\mathrm{Al}_{2} \mathrm{O}_{3}-\mathrm{CaO}-\mathrm{K}_{2} \mathrm{O}-$ $\mathrm{Na}_{2} \mathrm{O}-\mathrm{ZnO}$ system with variable content of $\mathrm{ZnO}$. J Therm Anal Calorim. 2017;128:1343-51.

50. Babu KS, Reddy AR, Reddy KV, Mallika AN. High thermal annealing effect on structural and optical properties of $\mathrm{ZnO}-\mathrm{SiO}_{2}$ nanocomposite. Mater Sci Semicond Process. 2014;27:643-8.

51. Taylor LS, Langkilde FW, Zografi G. Fourier transform Raman spectroscopic study of the interaction of water vapor with amorphous polymers. J Pharm Sci. 2001;90:888-901.

52. Lin-Vien D, Colthup NB, Fateley WG, Grasselli JG. The handbook of infrared and Raman characteristic frequencies of organic molecules. New York: Academic Press; 1991. ISBN 0-12451101.

53. Lewis IR, Edwards H. Handbook of Raman spectroscopy: from the research laboratory to the process line. New York: Marcel Deker Inc.; 2001. ISBN 0-82470557-2.

54. Babu BC, Buddhudu S. Analysis of structural and electrical properties of $\mathrm{Ni}^{2+}: \mathrm{Zn}_{2} \mathrm{SiO}_{4}$ ceramic powders by sol-gel method. J Sol-Gel Sci Technol. 2014;70:405-15.

55. Babu BC, Rao BV, Ravi M, Babu S. Structural, microstructural, optical, and dielectric properties of $\mathrm{Mn}^{2+}$ : Willemite $\mathrm{Zn} 2 \mathrm{SiO} 4$ nanocomposites obtained by a sol-gel method. J Mol Struct. 2017;1127:6-14.

56. Al-Nidawi AJ, Matori KA, Zakaria A, Zaid MH. Effect of $\mathrm{MnO}_{2}$ doped on physical, structure and optical properties of zinc silicate glasses from waste rice husk ash. Results Phys. 2017;7:955-61.

57. Mohamed N, Hassan J, Matori KA, Wahab ZA, Ismail ZM, Baharuddin NF, Rashid SS. Influence of Pr doping on the thermal, structural and optical properties of novel SLS-ZnO glasses for red phosphor. Results Phys. 2017;7:1202-6.

58. El Ghoul J, Omri K, Alyamani A, Barthou C, El Mir L. Synthesis and luminescence of $\mathrm{SiO}_{2} / \mathrm{Zn}_{2} \mathrm{SiO}_{4}$ and $\mathrm{SiO}_{2} / \mathrm{Zn}_{2} \mathrm{SiO}_{4}: \mathrm{Mn}$ composite with sol-gel methods. J Lumin. 2013;138:218-22.

59. Al-Hada NM, Saion E, Talib ZA, Shaari AH. The impact of polyvinylpyrrolidone on properties of cadmium oxide semiconductor nanoparticles manufactured by heat treatment technique. Polymers. 2016. https://doi.org/10.3390/polym8040113.

60. Gharibshahi L, Saion E, Gharibshahi E, Shaari AH, Matori KA. Structural and optical properties of Ag nanoparticles synthesized 
by thermal treatment method. Materials. 2017;10:1-13. https:// doi.org/10.3390/ma10040402.

61. Grigorie AC, Muntean C, Vlase T, Locovei C, Stefanescu M. $\mathrm{ZnO}-\mathrm{SiO}_{2}$ based nanocomposites prepared by a modified sol-gel method. Mater Chem Phys. 2017;186:399-406.

62. Tsai MT, Lu YF, Wang YK. Synthesis and characterization of manganese-doped zinc orthosilicate phosphor powders. J Alloys Compd. 2010;505:818-23.

63. Babu KS, Reddy AR, Reddy KV. Controlling the size and optical properties of $\mathrm{ZnO}$ nanoparticles by capping with $\mathrm{SiO}_{2}$. Mater Res Bull. 2014;49:37-543.

64. Davis EA, Mott N. Conduction in non-crystalline systems V. Conductivity, optical absorption and photoconductivity in amorphous semiconductors. Philos Mag. 1970;22:0903-22.

65. Mishra KC, Johnson KH, DeBoer BG, Berkowitz JK, Olsen J, Dale EA. First principles investigation of electronic structure and associated properties of zinc orthosilicate phosphors. J Lumin. 1991;47:197-206.

66. Karazhanov SZ, Ravindran P, Fjellvåg $\mathrm{H}$, Svensson BG. Electronic structure and optical properties of $\mathrm{ZnSiO}_{3}$ and $\mathrm{Zn}_{2} \mathrm{SiO}_{4}$. J Appl Phys. 2009;106:1-21. https://doi.org/10.1063/1.326844.

67. Lee CS, Matori KA, Ab Aziz SH, Kamari HM, Ismail I, Zaid $\mathrm{MH}$. Influence of zinc oxide on the physical, structural and optical band gap of zinc silicate glass system from waste rice husk ash. Optik Int J Light Electron Opt. 2017;136:129-35.
68. Zeng H, Duan G, Li Y, Yang S, Xu X, Cai W. Blue Luminescence of $\mathrm{ZnO}$ nanoparticles based on non-equilibrium processes: defect origins and emission controls. Adv Funct Mater. 2010;20:561-72.

69. Wakefield G, Holland E, Dobson PJ, Hutchison JL. Luminescence properties of nanocrystalline $\mathrm{Y}_{2} \mathrm{O}_{3}:$ Eu. Adv Mater. 2001;13:1557-60.

70. Lee CH, Kang YC, Jung KY, Choi JG. Phosphor layer formed from the $\mathrm{Zn}_{2} \mathrm{SiO}_{4}: \mathrm{Mn}$ phosphor particles with spherical shape and fine size. Mater Sci Eng B. 2005;117:210-5.

71. Sekita M, Iwanaga K, Hamasuna T, Mohri S, Uota M, Yada M, Kijima T. Strong Eu emission of annealed Y2O3: Eu nanotube and nano-sized crystals. Phys Status Solidi B. 2004;241:R71-4. https://doi.org/10.1002/pssb.200409064.

72. Nazarov MV, Kang JH, Jeon DY, Popovici EJ, Muresan L, Tsukerblat BS. Lattice parameter and luminescence properties of europium activated yttrium oxide. Solid State Commun. 2005;133:183-6.

73. Jung KY, Han KH. Densification and photoluminescence improvement of $\mathrm{Y}_{2} \mathrm{O}_{3}$ phosphor particles prepared by spray pyrolysis. Electrochem Solid State Lett. 2005;8:H17-20.

74. Fu Z, Yang B, Li L, Dong W, Jia C, Wu W. An intense ultraviolet photoluminescence in sol-gel $\mathrm{ZnO}-\mathrm{SiO}_{2}$ nanocomposites. J Phys Condens Matter. 2003;15:2867-73.

\section{Affiliations}

\section{Ibrahim Mustapha Alibe ${ }^{1,3}$ (D) Khamirul Amin Matori ${ }^{1,2} \cdot \mathrm{Hj}^{\mathrm{Ab}}$ Aziz Sidek ${ }^{1,2} \cdot$ Yazid Yaakob $^{2}$. Umer Rashid ${ }^{4}$ (i) - Ali Mustapha Alibe ${ }^{5,6} \cdot$ Mohd Hafiz Mohd Zaid $^{2} \cdot$ Salisu Nasir ${ }^{1} \cdot$ Maharaz Mohammed Nasir $^{2}$}

1 Material Synthesis and Characterization Laboratory (MSCL), Institute of Advanced Technology (ITMA), Universiti Putra Malaysia, 43400 UPM Serdang, Selangor, Malaysia

2 Departments of Physics, Faculty of Science, Universiti Putra Malaysia, 43400 UPM Serdang, Selangor, Malaysia

3 National Research Institute for Chemical Technology, Zaria, Kaduna State, Nigeria
4 Material Processing and Technology Laboratory (MPTL), Institute of Advanced Technology, Universiti Putra Malaysia, 43400 UPM Serdang, Selangor, Malaysia

5 Mechanical Engineering Departments, Federal Polytechnic Damaturu, Damaturu, Yobe State, Nigeria

6 Departments of Mechanical, Automotive, and Manufacturing, Faculty of Engineering and Computing, Coventry University, Coventry CV1 5FB, UK 